\title{
Returning to Radburn
}

\author{
Michael David Martin
}

Michael David Martin, ASLA, CELA, SACRPH (BLA University of Georgia 1982; MLA University of Oregon 1995) is a licensed landscape architect, an Assistant Professor of Landscape Architecture at Iowa State University, and a former partner of the Atlanta, Georgia-based landscape architecture/land planning firm Reece, Hoopes and Fincher. His research interests are focused on the subject of neighborhood and community planning.

\begin{abstract}
The "new urbanist" vision for contemporary neighborhoods looks back to the streetscapes of the pre-automobile era for inspiration, intentionally overlooking the automobile-adaptive community design era which began in America with Clarence Stein's and Henry Wright's "Town for the Motor Age" Radburn in the late 1920s. New urbanism establishes a theoretical position fundamentally at odds with "garden city" design principles which differentiate streetscapes and community open space. New urbanists do this by downplaying or ignoring the conflict inherent in the idea that a neighborhood street should attempt to serve as civic interface while simultaneously serving as the outdoor focus for neighborhood social life. The author proposes that experimental and innovative Radburn, rather than pre-modern, pre-automobile town design, is the logical starting point for understanding how to form contemporary neighborhoods, because Radburn actually began to address the dilemma posed by the new automobility. Subsequent "garden city" experiments such as the American New Towns of the 1960s and later planned unit developments paid homage to Radburn, but abandoned particular radical aspects of the Radburn concept; thus we have not witnessed the true evolution of Radburn in North American suburbia. However, the few planned communities which did remain true to Radburn's radicalism, such as Winnipeg, Manitoba's postwar Wildwood Park, do reflect this evolution. This paper will address the fundamental opposition that constitutes the relationship between new urbanism and the Radburn concept, and will reveal that the present-day landscapes of Wildwood Park and of Radburn itself have evolved to offer insights for how the Radburn concept can be adapted for contemporary community planning.
\end{abstract}

Radburn: the Hardy Perennial of Archetypes

Among American planned communities of the twentieth century, Radburn in Fair Lawn, New Jersey stands as the exceptional archetype. Radburn is routinely cited by planning historians as a benchmark community design, the prototypical American suburban expression of Ebenezer Howard's "Garden City" idea (Richert and Lapping 1998; Howard 1902) which had found earlier expression in Sir Raymond Unwin's English New Towns (Unwin 1932). ${ }^{2}$ Radburn too was conceived at the scale of a town, but the development process ran aground abruptly at the onset of the Great Depression. From a historical perspective, this hardly mattered; despite its failure to grow beyond the limits of an initial phase (Figure 1) and its failure to realize the holistic vision of the Regional Planning Association of America (RPAA), ${ }^{3}$ Radburn's influence on subsequent American new town experiments such as the three New Deal-era Greenbelt Towns (The

U. S. Resettlement Association 1936) ${ }^{4}$ and the much larger-scaled Great Society-era New Towns was profound. ${ }^{5}$ In the 1970 s Radburn emerged once again as a significant prototype, serving as the conceptual model for the early "ecoburb" of Village Homes in Davis, California (Corbett 1981; Girling and Helphand 1994; Corbett 2000). ${ }^{6}$

\section{The New Urbanist Repudiation of Radburn}

Scholarly studies of Radburn itself, which recently celebrated its 80th anniversary, abound in planning literature in the form of books, research articles, and graduate theses and dissertations (Girling and Helphand 1994; Christensen 1986; Schaffer 1982; Filler 1982; Birch, 1980; Stellhorn, 1978). ${ }^{7}$ Radburn has been repeatedly described, analyzed, extolled and criticized from the perspective of historians, planners, de- signers, and social critics; what brings Radburn to light in contemporary discussion is the rhetoric and critical perspective of the recently emerged town planning trend known as "new urbanism" (Duany et. al. 2000; Leccese and McCormick 1999; Schmitz and Bookout 1998; Fulton 1997; Katz $1994)^{8}$. In the critical tradition of Jane Jacobs, (Gladwell 2000; Jacobs $1961)^{9}$ new urbanists have the hyperopic tendency to dismiss Radburn as a "failure" (Calthorpe 1993), ${ }^{10}$ regarding its landscape (as opposed to streetscape) orientation, its introverted cul-de-sacs and its calculated spurning of the traditional streetscape as the very embodiment of anti-urbanism, as the apex of the twentieth-century momentumgathering slide down the slippery slope toward twenty-first century suburban sprawl. For new urbanists, Radburn is a cautionary tale, an example of how to get things badly wrong. And no wonder: Clarence Stein's design concept for Radburn, the foundation of which was that residents and cars should not mix within the 


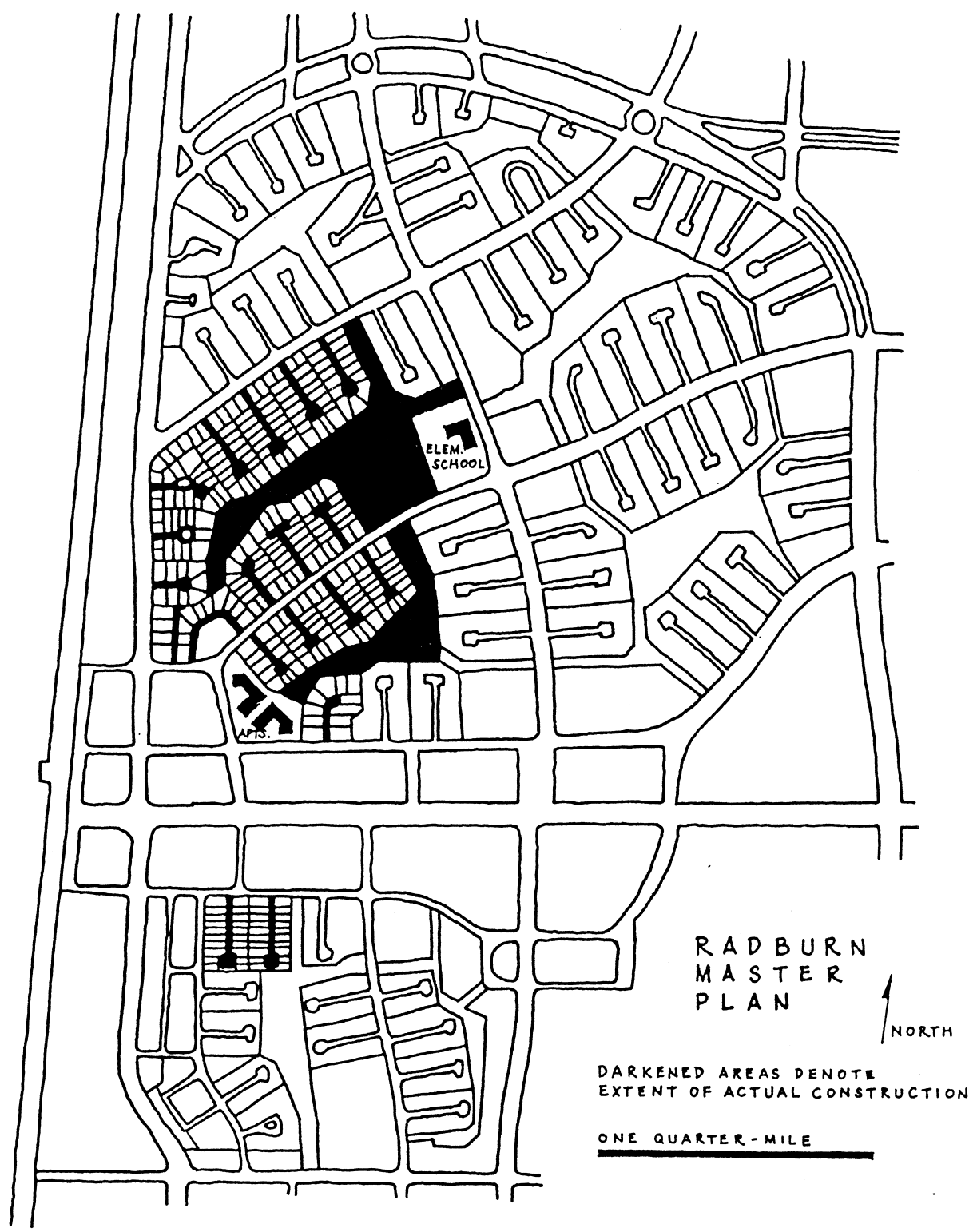

Figure 1. Radburn as envisioned and Radburn as-built. Most of the area not yet developed prior to the economic crisis of 1929 was later re-platted for more standard forms of residential development. (Drawing by author.)

primary community space, is fundamentally at odds with the new urbanist vision for livable, public streets. New urbanism has repudiated the Radburn idea.

The clearest, and perhaps at this point the most widely disseminated evidence of this repudiation, can be found in the recent editions of Architectural Graphic Standards, the reference "bible" for architects, planners, and landscape architects. A group identified as "The Cintas tive disadvantage is its "concentration of traffic by absence of network"

(Hoke 2000, p. 88) - a criticism that is of course balanced by the "trafficcalming" benefits inherent in a street plan which accommodates only local traffic. It is also, in this particular case, an invalid criticism, since a problematic degree of "concentration of traffic" would occur only beyond a certain scale of development or beyond a certain extent of a dendritic street pattern-a scale far greater than that of the compact Radburn system of streets and lanes (a typical Radburn lane is a scant 400 feet in length). What is even more revealing about the new urbanist predisposition is what is missing from this essential and widely respected reference volume. In the "block types" section, several block conformations are diagrammed, but no culde-sac infiltrated "superblock" appears (Hoke 2000, p. 89). And under the "open space type" heading, only open spaces directly bounded at least in part by streets make their appearance-no protected Radburn-style interior spaces are to be found. (Hoke 2000, p. 89) All this is quite consistent with the new urbanist assertion that the very concept of community open space is meaningless when the open space is detached from the very public street network, and the effective censorship of examples of detached interior open space from the featured planning typologies demonstrates the totality of the new urbanist dismissal of this landscape.

The new urbanist argument is that the Radburn concept was far too radical, an example of overreaching modernism and cultural discontinuity, heedlessly tossing aside traditional town-making principles grounded in centuries of urban experience (Krieger 1991). ${ }^{11}$ With his "Town for the Motor Age," new urbanists maintain that Stein was not adjusting to the reality of motoring in everyday life so much as he was running away from the problem, leaving a trail of unintended consequences in his wake. The new urbanists are only the latest critics to point out that Radburn not only lacks proper public streetscapes but that the 
neighborhood is intently inwardly focused, a landscape island lacking meaningful connections outside of itself. This critical position has merit, but the new urbanist counterproposal seems to be little more than the triumph of hope over experience. New urbanists offer beautifully nostalgic visions of small-town-living, front-porch-sitting, sidewalk-strolling, parallel-parking ${ }^{12}$ contentment (Figure 2), but there has yet to emerge a new urbanist design proposal which confronts the fundamental issue that Stein so famously and radically confronted over eighty years ago: motoring can be dangerous for pedestrians.

The automobilization of everyday life was a dramatic social discontinuity, and an inescapable, inevitable one; any coherent vision for new community form cannot disregard this obvious truth. New urbanist communities are indeed an attractive alternative for certain demographic groups-particularly "DINKs"13 (double income-no kids) and emptynesters-but those same DINKs will often flee to the protective cover of a Radburn-inspired garden suburb culde-sac as soon as their firstborn becomes a pedestrian. For all its antiurbanity, Radburn did one thing very well: its landscape protected children, not just from cars but from the uncertain dangers inherent in the very publicness of the community street. For a contemporary designer to consider that a community's "ges-

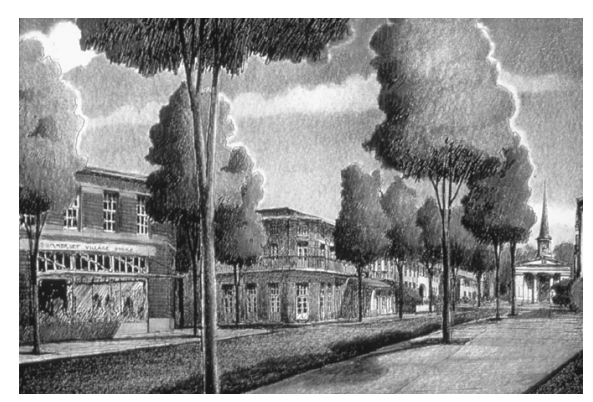

Figure 2. The oddly car-less twenty-first century new urbanist streetscape marketing vision: town center view in the Somerset development in Ames, Iowa designed by Duany Plater-Zyberk \& Company. (Image used with permission of DPZ.) ture" of openness toward public streets (and by extension to the wide world to which these streets provide direct linkage) is a matter of civic duty is not simply to ignore or deny the very real problems this poses for resident children and their families; it also constitutes a dismissal of the seventy-year-old cultural legacy of Radburn: a pervasive American suburban landscape that reflects to an equivalent degree both the love of and fear of the moving automobile.

\section{Reconsidering Radburn's \\ True Radicalism}

To acknowledge this evolved postwar suburban landscape as a logical, protective cultural response is not tantamount to accepting its form as inevitable; neither does this acknowledgment address the perfectly reasonable criticisms leveled by suburbia's detractors. What it does do is suggest that the starting point for reimagining the twenty-first century community is not the charmingly antique urban landscape that preceded automobiles, but is rather those places that demonstrate the early, partly successful attempts to reconcile the car and the home neighborhood landscape - that would be Radburn itself, and the very few of its imitators that were faithful to its concept. It makes sense to begin with the observation that Radburn was extraordinarily successful in at least that one essential responsibility: the protection of resident children. ${ }^{14}$ Next, it is necessary to discern how Radburn accomplished this goal, in order to understand what the implications are for contemporary practice. After this point, one would be in an appropriate position to begin to critique the Radburn scheme's shortcomings, and would be thus equipped to suggest adjustments or alternative arrangements that could conceivably refine the concept for contemporary living.

As noted above, Radburn was the inspiration for many subsequent suburban community forms. It would be a mistake however to assume that the 1930s Greenbelt Towns, the 1960s New Towns, and the innumerable planned unit developments (Jarvis 1993) ${ }^{15}$ of the latter third of the twentieth century which appropriated the Radburn interior openspace pattern were continually refining the Radburn concept. These ubiquitous examples are Radburn's successors, but they do not really represent the evolution of the Radburn idea because Radburn is a "fragment" in more than just the physical sense. Not only was the original more comprehensive scheme aborted, with development halted after the construction of only two incomplete superblocks (Figure 1) ${ }^{16}$ (Radburn might more accurately be described as a "garden neighborhood" than in any respect as a garden city) - more importantly, the essential radicalism of Radburn was abandoned as well. Stein did indeed establish substantial and continuous pedestrian open space as the organizing principle of his plan, which is the aspect of Radburn often imitated. But this was only the starting point-even in the existing fragment he went much further in two important ways, both of which reflect his antipathy toward the street as inhabitable community space.

First, he reversed the homes, and had them actually face the interior park. Second, he reduced the streets to a minimalist scale, to the point where they were no longer streets even in name-seventy-plus years later, residents still refer to them as "lanes," just as Stein had them labeled on his plans. In reality they are little more than communal driveways or unusually well kept dead-end ${ }^{17}$ back-alleys.

In reversing the homes and minimizing the streetscape, Stein meant to force community life to focus inward, onto its interior park. Reasoning from the perspective of a late 1920s planner, he did not imagine the extent to which the automobile would eventually become central to routine activities in the lives of not only commuting wage-earners but of all residents, even "homebound" mothers and children. He had intended for Radburn's park to be not just safe passage for children to and from school and between neighboring homes, but for the park to be- 
come the social matrix for family members who would only rarely have occasion to venture beyond the community's limits. In other words, the park was meant to displace the street, and the only role left for the street was one of service access and car storage. In later decades, Stein's successors acknowledged the more prominent role of the automobile by abandoning both of Stein's truly radical strategies. The 1960s New Town Columbia, Maryland, for example (Tennenbaum 1996), replicates Radburn's superblock ${ }^{18}$ and gradeseparated pedestrian street crossings, ${ }^{19}$ but features both streetfacing houses and a full-scale suburban street network (Martin 1999). ${ }^{20}$

New Town planners of the 1960s surely believed that what they had done was to borrow from Radburn's successes while avoiding its oversights, updating the concept to accommodate the modern reality of vastly increased automobile use. What they perhaps did not adequately consider is what they gave up in the process. By editing out Radburn's radical "mistakes," suburban planners may well have overlooked the potential for a truly innovative response to the expanding role of the automobile in community life.

It must first of all be acknowledged that the "reversed" home is indeed a problematic concept, because any house is more than simply a unit of domestic architecture-it is a landscape entity bounded by differentiated territorial zones which govern particular associated domestic social conventions (Rapaport 1969). Turning the home's traditionally "public" face away from the street has dramatic implications for both the street as well as for the landscape that develops on the opposite side. As this author noted in his study of the history of Winnipeg's Radburnesque Wildwood Park:

This reversal [of house orientation] creates at once both the opportunity for enhanced connections among residences along with a certain degree of social-landscape ambiguity. In short, the reversed concept has both salient strengths and apparent drawbacks, and because of this the arrangement has never really gained any significant degree of acceptance among developers in North America. (Martin $2001)^{21}$

Radburn's reversed homes are still something of a curiosity because this strategy has not often been adopted for subsequent developments of single- or even two-family housing. While it is certainly routine practice to "reverse" the front entries of medium- and higher-density apartment or townhouse residences toward their common open spaces and away from their parking lots, it is unusual to find lower-density neighborhoods in North America that forsake the traditional streetscape in order to remain faithful to this particular Radburn innovation. The primary drawback is easily imagined: confusion and uncertainty for "outsider" visitors seeking walk-up access which cannot be discerned from the approach by car. Walk-up access, as opposed to drive-up access, is often necessary at Radburn, at least for visitors. Stein's reduction of the internal streetscape adds further difficulty for the visitor, as the lanes themselves typically fail to provide adequate guest parking. ${ }^{22}$

The question that occurs is whether the parking convenience/ visitor approach issues are so important as to warrant abandonment of either the reversed concept or the minimum-capacity lanes. In the first place, is parking and approach convenience a singular prerogative of lower density neighborhoods, or might we accept this condition here as we commonly do in neighborhoods of higher densities? Secondly, it is the new urbanists themselves who routinely advocate parking and approach inconvenience in retail and institutional settings by locating parking lots out of view, behind buildings-all for

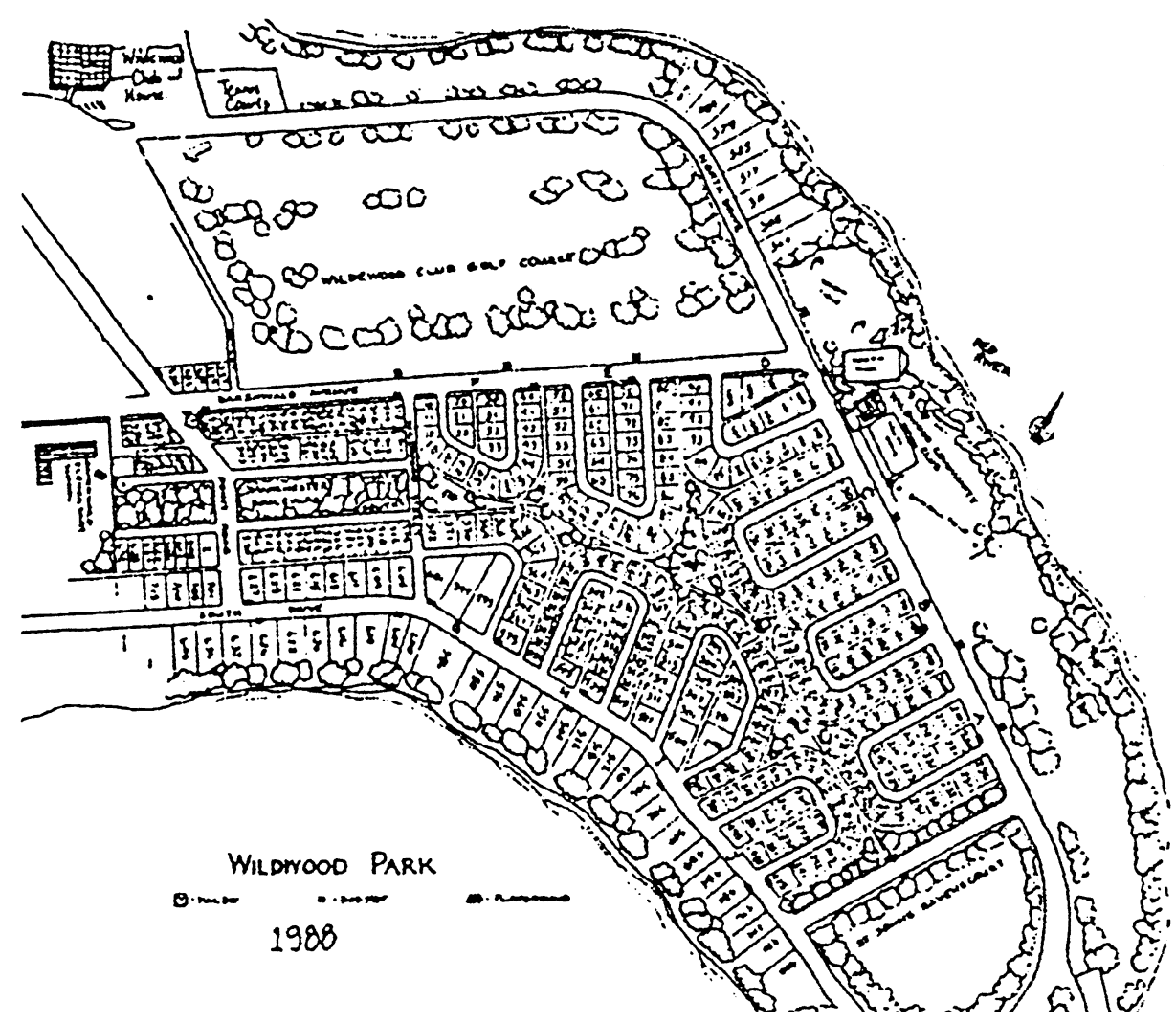

Figure 3. Wildwood Park illustrated in plan view. (Plan used with permission of Wildwood Park History Book Committee.) 


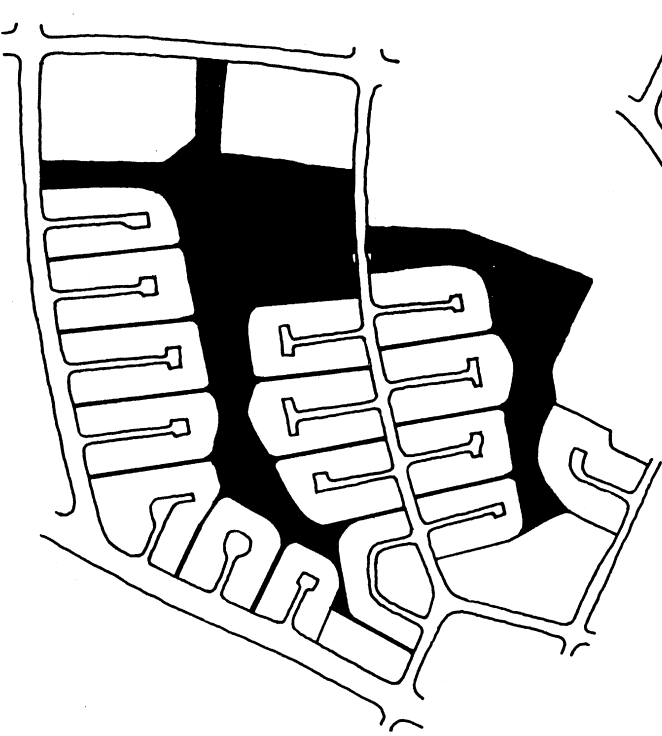

Figure 4. Same-scale diagrammatic comparison of street/open space schemes of Radburn (left) and Wildwood Park (right). (Drawing by author.)

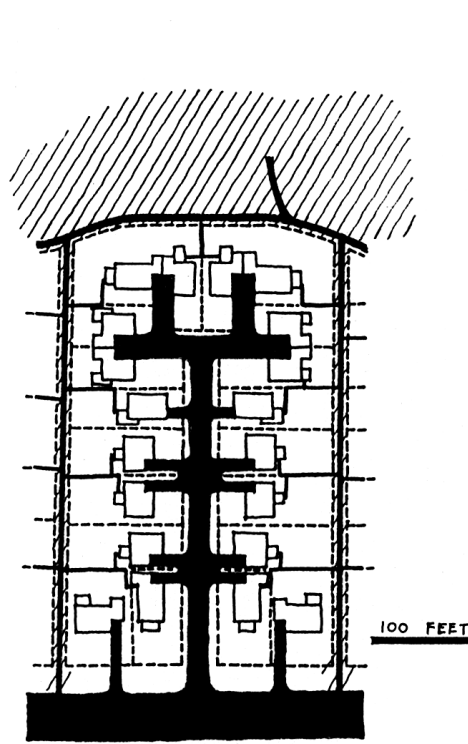

RADBURN HAMMERHEAD

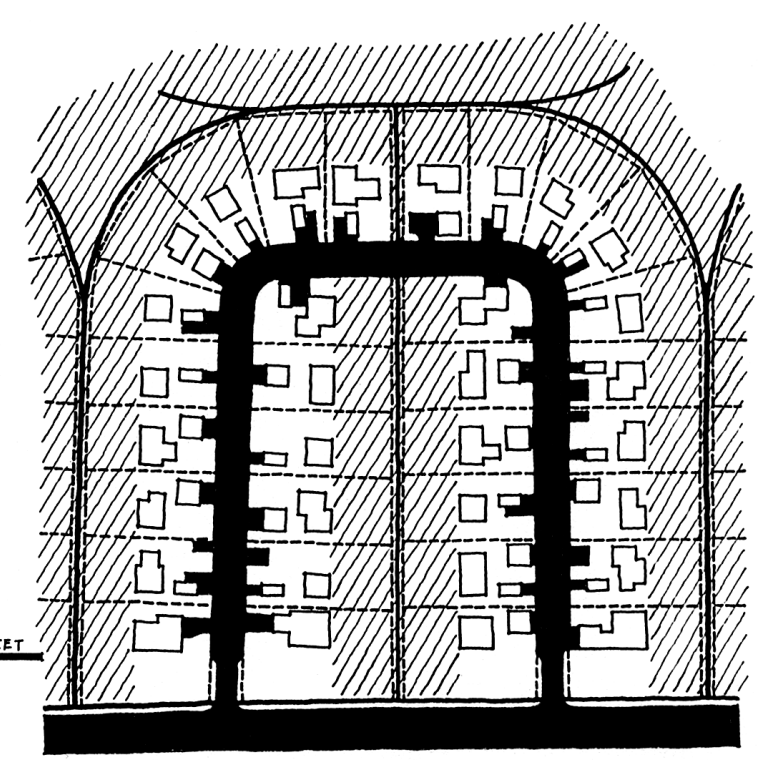

WILDWOOD PARK LOOP-LANE
Figure 5. Same-scale comparison of a typical Radburn lane and a typical Wildwood Park loop-lane. Hatched areas denote extent of visually accessible front-yard park space. (Drawing by author.) the sake of the pedestrian and for the visual quality of the streetscape. Radburn does provide for visitor parking, parallel-style on the streets that define the edges of the superblocks. This may, of course, necessitate a walk of up to a few hundred feet for the visitor.

The initial premise is that it is worth reconsidering the visitor's convenience issue, for the sake of investigating the potential of the reversed concept and the neighborhood lane to provide contemporary inspiration for neighborhood-scale design. While we must acknowledge the inherent ambiguities and difficulties posed by Stein's solutions, we can also bear witness to their positive implications for community-building. It should also be obvious that experimental Radburn itself was not and is not the final word on the reversed pattern. While Radburn has had few true imitators, some do exist, and a beginning point for a contemporary analysis of reversed homes and lanes might be a study comparing and contrasting Radburn with other neighborhoods which adhered to Radburn's radical design principles, but carried the experiment further by modifying other essential siteplanning parameters. Wildwood Park in Winnipeg, Manitoba is one such example.

\section{Radburn and Wildwood Park: \\ the Evolution of an Idea}

Wildwood Park is a contemporary of Long Island, New York's Levittown and, like Levittown and hundreds of other North American starter-home developments of the late 1940 s, was built to meet the intense postwar housing demand created both by the lag in new home construction during the war years and by the horde of prospective home-buying veterans who were in turn financially backed by new federal home-loan programs in both Canada and the United States (Harris and Larkham 1999; Bacher 1993; Doucet and Weaver 1991; Miron 1988; Smith 1974).$^{23}$ Wildwood Park was directly inspired by Radburn, ${ }^{24}$ and builder/developer Hubert Bird sought to create the same sort of 
community focus on a common interior landscape. Unlike most Radburn admirers, Bird bought wholeheartedly into Stein's radicalism. Bird's preliminary scheme, designed by the architecture firm Green, Blankstein and Russell (GBR), reversed the homes to arrange them around a central open space contained within a single seventy-five-acre superblock, and backed them upon an internal street pattern which featured a blend of Radburnesque "hammerhead" culde-sacs and U-shaped looped lanes (Figure 3). In their design review the architects and planners in the Canadian Housing Administration's Ottawa office offered high praise for the scheme but cautioned that the hammerheads would make for difficult access by delivery vehicles, and recommended circular turnarounds in lieu of the hammerheads. ${ }^{25}$ In response, Bird and GBR simply eliminated all the cul-de-sacs in favor of more looped lanes.

This variation in street pattern constitutes the most immediately apparent difference between the plans of Radburn and Wildwood Park (Figure 4). Not only did this strategy improve vehicular maneuverability, it had the further consequences of increasing each lane's population ${ }^{26}$ and of fragmenting the matrix of the "front yard" landscape such that each of the ten loops contained an appendage of the central open space (Figure 5). A second important distinction in the plan was the dimensional relationship between homes and lanes, and the provision for excess parking along lanes. In Radburn, as noted previously, the lanes are minimally proportioned, providing little more than access to resident garages and the occasional odd parking space adjacent to the back side of a house. Radburn's houses are set very closely to their lane's edgesometimes only about twenty feetwhich both constrains opportunities for visitor parking and compresses back yard dimensions to a minimum (Figure 6). In Wildwood Park, Bird had his designers provide for a true back yard, setting houses about fifty feet from the lane's edge; in addition, the thirty-foot Wildwood Park

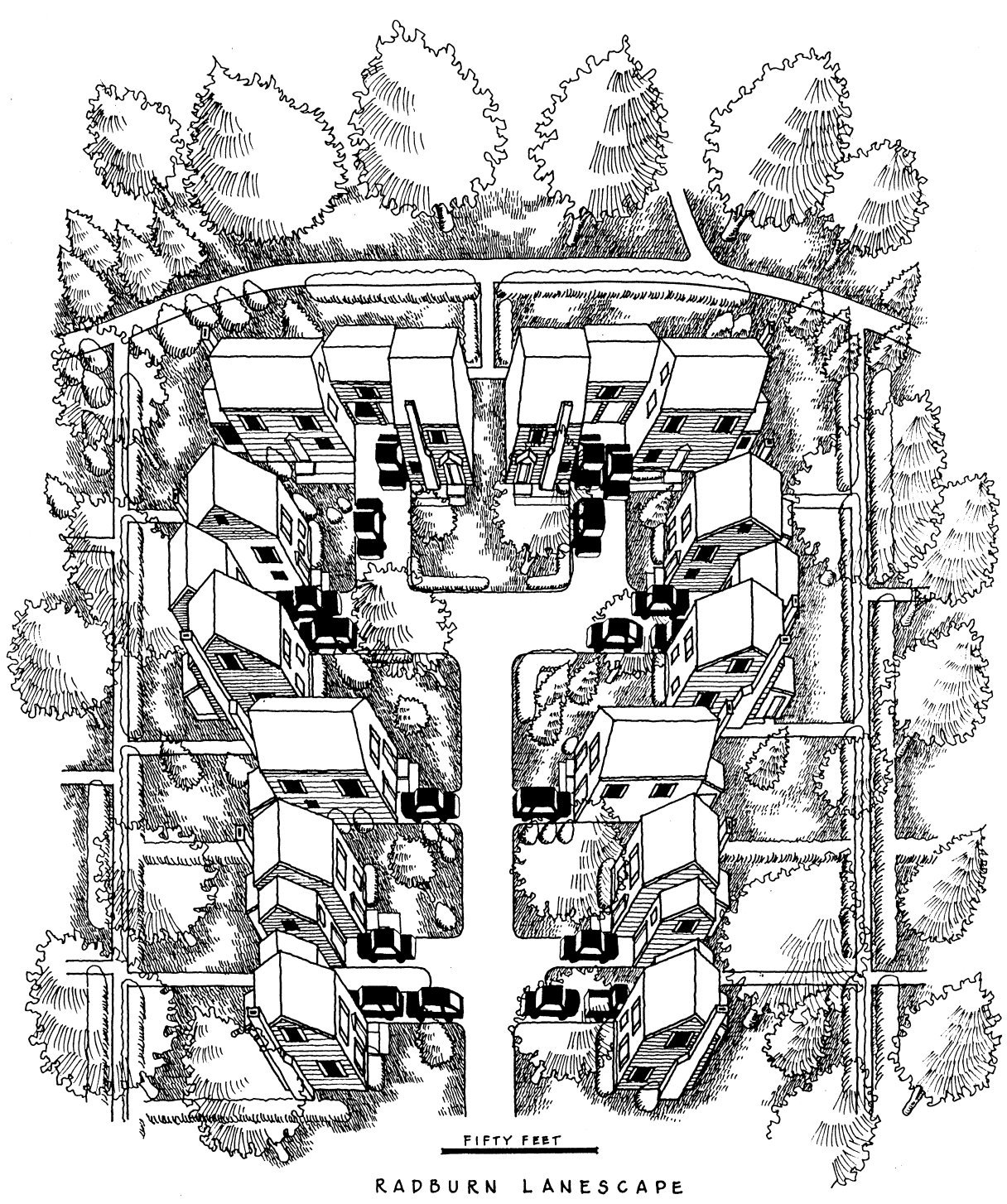

Figure 6. The figured ground of the Radburn hammerhead lane-scape. Minimal lane-side yard space constrains most backyard uses other than car storage. (Drawing by author.)

lane cross-section was designed specifically to accommodate parallel parking along both sides (Figure 7).

\section{Parks and Lane-scapes as "Figured Ground"}

The essential distinctions between these two communities, however, transcend the limitations of a plan-view analysis; any meaningful assessment of their respective landscapes requires an engagement with what Elizabeth Meyer would describe as their experiential "figured ground" (Meyer 1997).${ }^{27}$ Each community features as its organizational framework an extensive "park" landscape that connects the front sides of homes, but these two parks have dramatically different origins. The land upon which Radburn was built in the late 1920s had been a topographically level spinach farm, featuring no significant drainage ways and essentially no vegetative landscape structure. As a response to this daunting visual barrenness, Stein engaged the services of landscape architect Marjorie Sewell Cautley to transform a 
farm into a park. Cautley designed foundation and territorial "edge" planting for each home's front yard and established trees within the broad intervening spaces upon which some of the front yards faced. ${ }^{28}$

Seventy years later, Cautley's legacy is twofold. The park's broad interior landscape has fully matured, replete with an umbrageous canopy which belies its treeless agricultural heritage. (These days, as the original plantings mature and decline, they

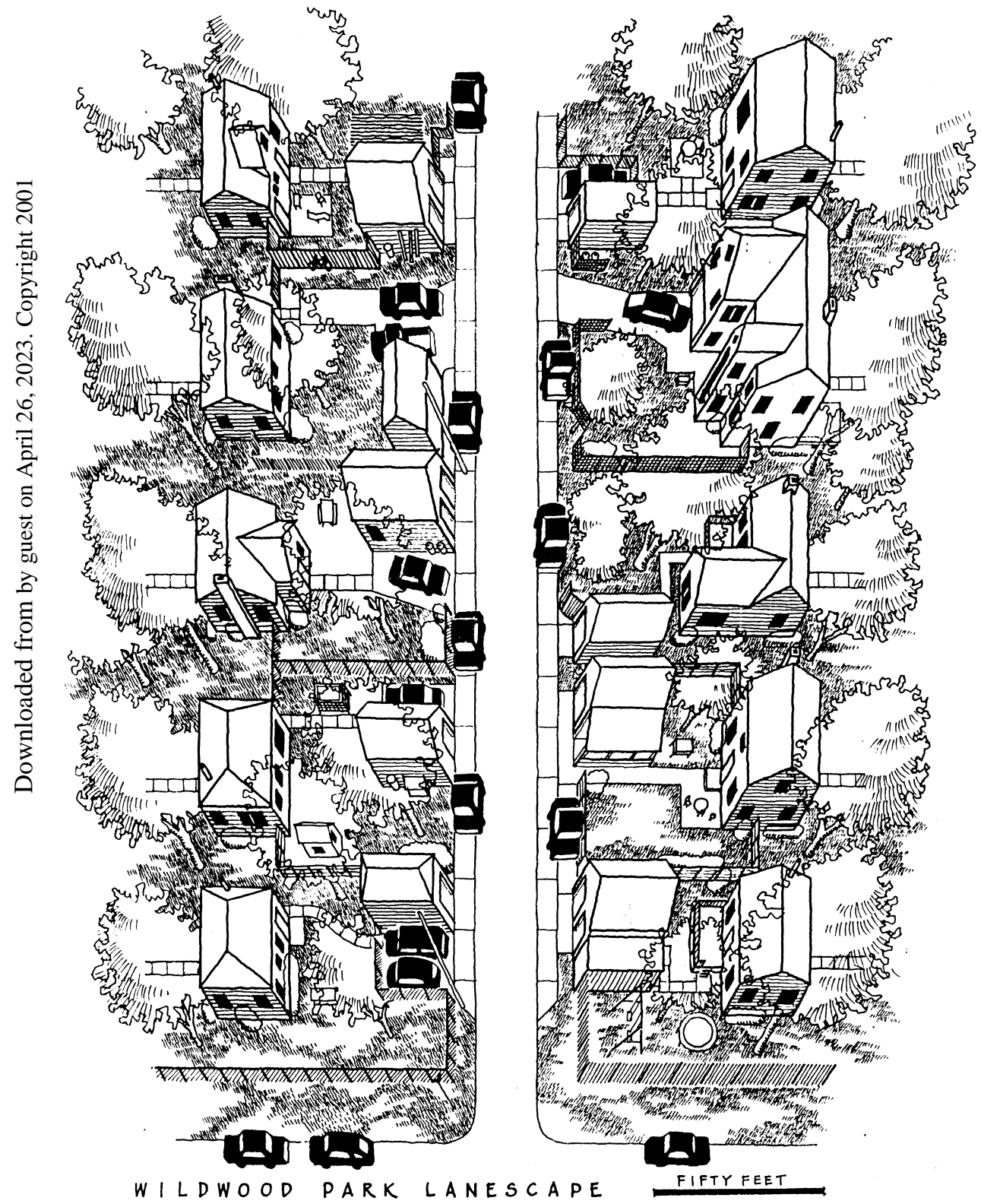

Figure 7. The figured ground of the Wildwood Park lane-scape. Diverse and routine use of backyards activate the lane-scape as an intimate social domain. (Drawing by author.) lane, and is less frequently observed bordering homes located at the terminus of the lanes which face the more generous dimensions of the broad pastoral interior. Peeking over or through these pathway-hugging hedges, one can find privatization of outdoor space in the form of small decks and patios (Figure 9). ${ }^{30}$ This

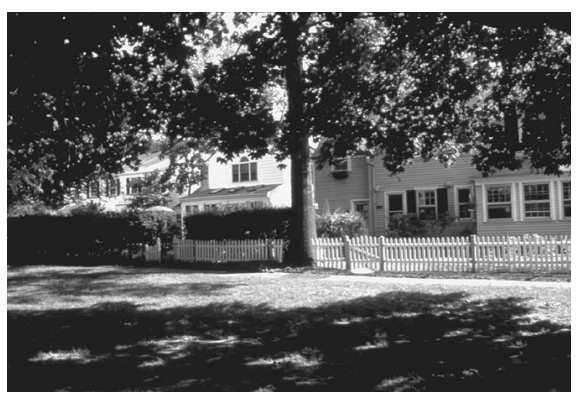

Figure 8 . The varying permeability of the landscape interface between Radburn front yards and the common park. Cautley's edge plantings were installed to demarcate territory and reduce spatial scale in the treeless expanse of an erstwhile spinach farm. (Photo by author.)

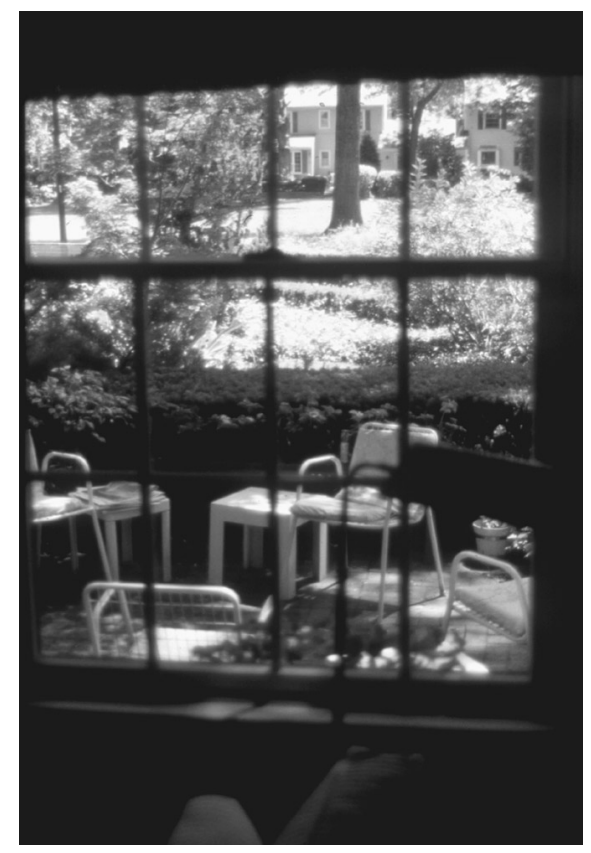

Figure 9. A Radburn front-yard patio, as seen through the living room window of the residence; interior open space, and the fronts of other residences, can be seen in the background. (Photo by author.) 


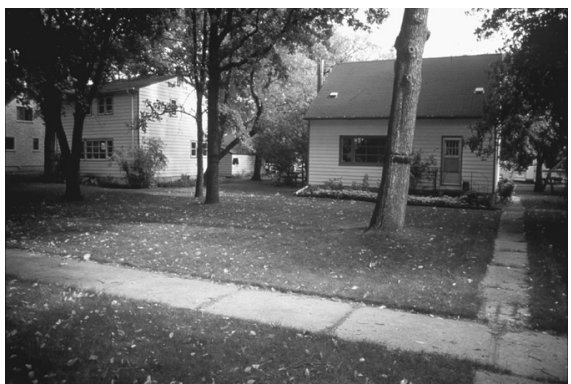

Figure 10. Expansive openness is the norm among Wildwood Park front yards; view is from the interior of a loop-lane section. (Photo by author.)

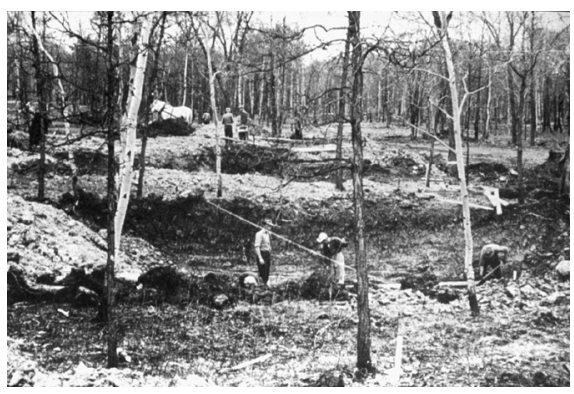

Figure 11. Digging foundations while saving trees at Wildwood Park during construction in 1947. (Photo used with permission of Wildwood Park History Book Committee.)

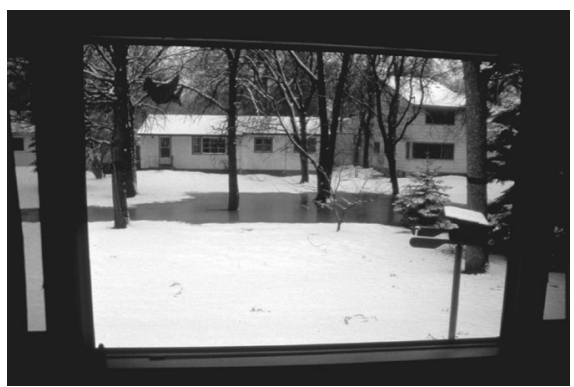

Figure 12. An early spring view through a Wildwood Park living room's "picture" window, across the front yard to the front of another home. Some of the park's lessfrequently-used walkways are impassable during Winnipeg's lengthy snow season. (Photo by author.) feature reflects a certain ambivalence-a conflicting impulse to both "belong" to the landscape commons and to be at least partially protected from its publicness. This ambivalence is also manifested in Radburn's contemporary management practices. While there have been no attempts to remove or reduce Cautley's original edge plantings, residents are not free to establish visual barriers along front yard edges where they do not yet exist. ${ }^{31}$

The "park" in Wildwood Park offers a distinct contrast. It too is filled with mature trees, but most of the homes maintain a visually open relationship with the interior (Figure 10). It turns out that this has everything to do with the original landscape condition-Bird had chosen for his development a parcel within a forested floodplain, so the trees were already there at the time of construction. For years prior to development, Bird had lived adjacent to this woodland, which was almost surrounded by a sharp bend in the wide, sluggish Red River. He had frequently hiked the land, paddled a canoe along its river edge, and contemplated a variety of development scenarios which might best integrate with the indigenous landscape (Nelson and Crockett 1984; Reimer 1989). As a consequence, Wildwood Park reflects both an abstract planning philosophy as well as a place-specific landscape conservation approach.

One might question whether it matters how the park became a park in these two developments; the difference is reflected in the nature of the landscape relationship between homes and park. Bird directed his construction crews to save as many trees as possible, so they even dug foundations by hand where necessary (Figure 11). With a forest in place throughout the park from the beginning, there was little incentive to add more plantings to demarcate territory or to scale down the open space. Architecture played a role as well; Bird's small prefabricated starter homes all featured "picture windows" looking out to the leafy expanse of the park, immediately establishing a valuable "viewshed" for each residence which residents have sought to maintain for over fifty years (Figure 12). Initially, there were no neighborhood bylaws which prohibited frontyard screening, but in any event the practice was rare and generally frowned upon because it was considered antisocial (Nelson and Crockett 1984)..$^{32}$ In 1984, after thirty-five years had passed and the population had diversified, residents amended the bylaws to proscribe fences or "... . landscaping features ... placed in a front yard in such a manner as to provide a fence effect" (Bayne 1945, amended 1984)..$^{33}$ This came about because a few modest front-yard plantings had matured to the point where they were breaking up long views under the tree canopy within the park. Although this had happened only in isolated cases, such was the reverence for the open park landscape that the proposed amendment to the bylaws passed a homeowners' vote with only one dissension out of one hundred votes cast.

\section{Complementary Front and Back Landscapes}

There is another factor which bears directly upon the difference in these two park landscapes: the consideration for how the design of the respective lanes affected the landscape on the other side of the houses, for the front and back landscapes are inextricably linked (Figure 13). At Radburn the home property adjoining the lane is minimal, and hence there is little if any opportunity for use or individual expression in these places. Radburnites who wish to control some portion of their own outdoor property have little choice but to attempt to do this in the front yard - that is, the yard adjoining the park or adjoining the pathways which lead to the parkhence the frequent incidence of "privatization" of the spaces between the home and the park and the resulting problem of conflicting impulses mentioned earlier. In Wildwood Park, on the other hand, there is a small but (when compared with Radburn) relatively generous rear-side plot of land which residents are free 


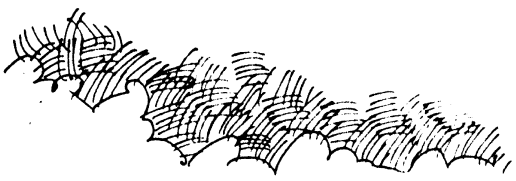

POST-DEVELOPMENT PLANTING SCHEME

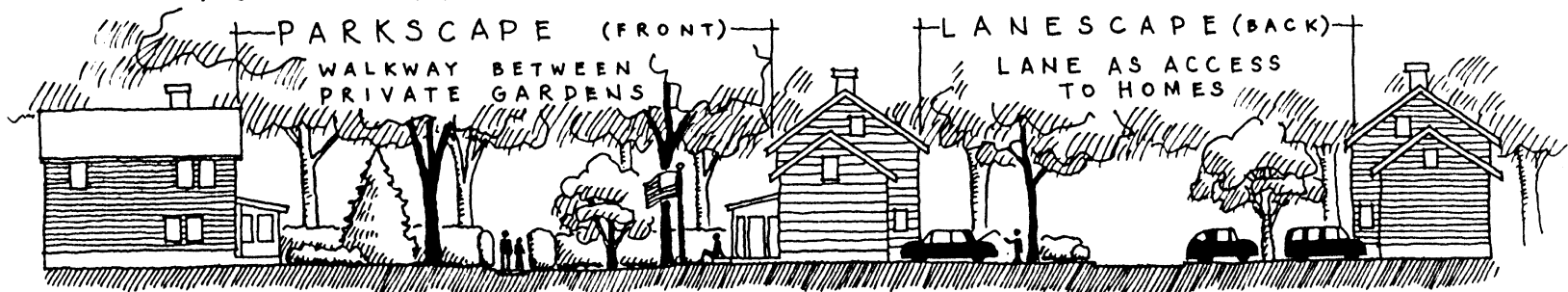

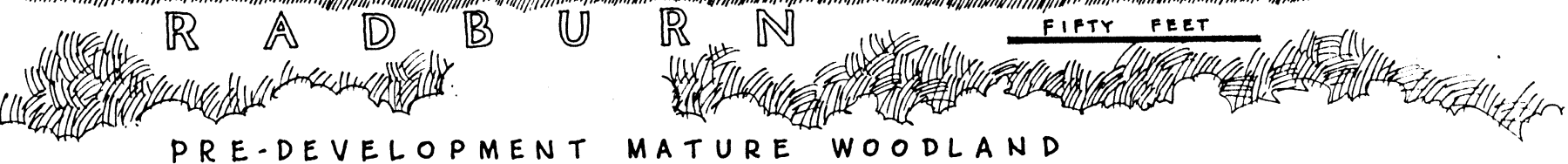

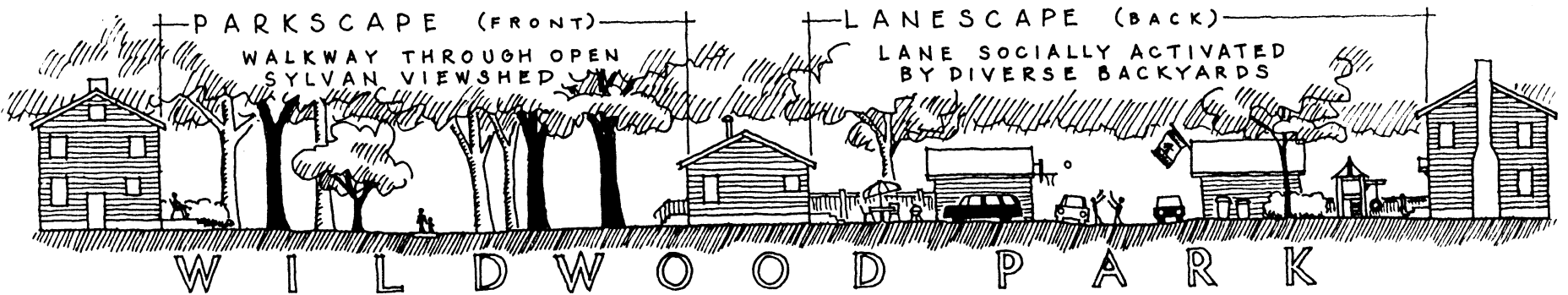

Figure 13. Same-scale sections through Radburn (top) and Wildwood Park (bottom) front yards and back yards. Note how Cautley's plantings at Radburn serve to structure front yard space for privacy, and note the importance of detached garages in structuring Wildwood Park's lane-scapes. (Drawing by author.)

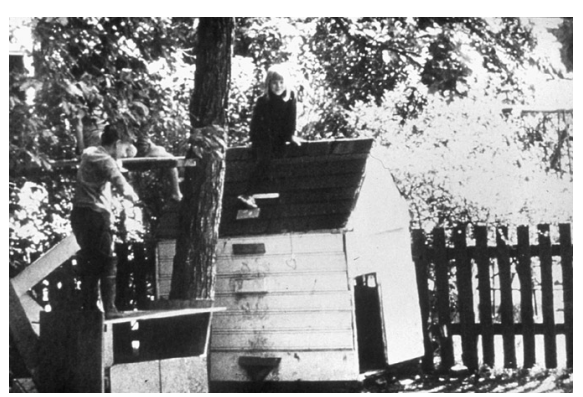

Figure 14. A playhouse installed along a lane-edge fence in Wildwood Park. Residents have the freedom to construct their backyards as needed to suit their diverse needs. Photo ca. 1974 by Siegfried Toews, and used with his permission.

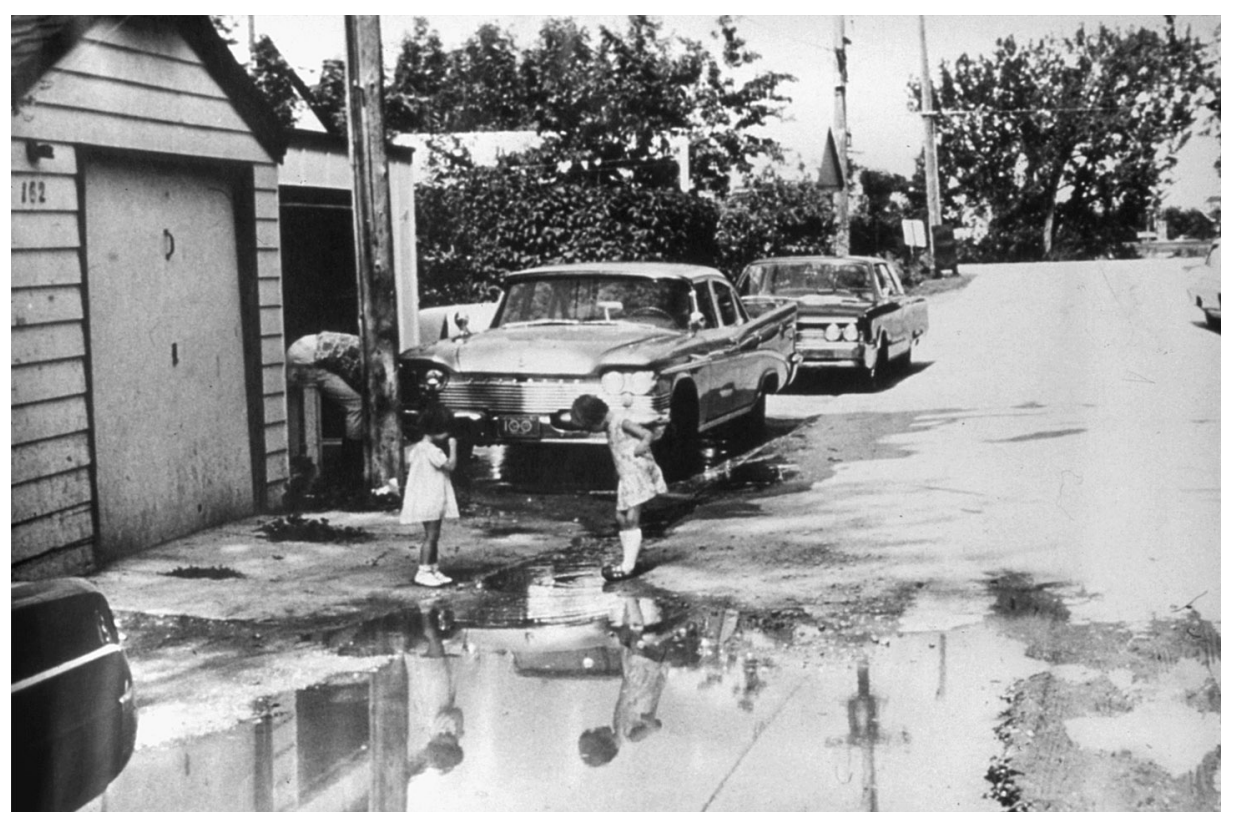

Figure 15. A diversity of everyday activities activates the Wildwood Park lane-scape. Photo ca. 1974 by Siegfried Toews, and used with his permission. 
to shape according to their needs (Figure 14). This is where one will find nearly all of the "privatization" and most of the individualized landscape expression in Wildwood Park. Significantly, this space is on the informal "service" side of the house, so it is contiguous with the kitchen, the kitchen's window, and with the doorway that is used most frequently for arrival, for departure, and for general access. These rear yards in Wildwood Park are widely diverse and interesting places because each reflects or reveals the habits or desires of the individual resident families. Most residents have built garages within these yards, and for many the yards are primarily used for car storage. But there are also a great variety of other uses to be found on a stroll along the lane: fenced yards for children or pets, rabbit hutches, low wooden decks, patios, paved walkways, outdoor furniture, barbecue grills, detached storage sheds, miscellaneous play structures, ornamental gardens, kitchen gardens, staging area for outdoor construction projects, and so forth. Many are neatly maintained, and some seem to be in a constant state of unself-conscious casual disorder. They are truly "libertarian landscapes," and the reason they are comfortably liberated from the burden of enforced orderliness is that Wildwood Park residents have willingly accepted those burdens for the landscape on the other side of the house, the side that fronts the park.

A criticism of Stein's plan for Radburn, having as we now do the hindsight afforded by several decades of landscape evolution in both neighborhoods, is that he did not provide families with sufficient space for semi-private outdoor use or personalization-nor did he really understand how the park or lanes would come to be used socially, a fact he acknowledged in the early 1950s upon revisiting Radburn after a full generation of landscape adaptations had occurred. ${ }^{34}$ Based on neighborhood cultural landscapes across a broad spectrum of housing development types, one might surmise that any neighborhood will tend to develop a "formal" side, which reflects qualities of orderliness, homogene- ity, presentation and a sense of belonging to something greater. As landscapes of social expression and social function, "fronts" and "backs" of neighborhoods correspond with sociologist Erving Goffman's dramaturgical theory of human interaction (Goffman 1991). Goffman has theorized that the human social personality is partly composed of a "presentational front" where social "performances" (Goffman 1959) are conducted just as a playwright creates a stage-set as the scenographic milieu, replete with props and costumes, for the actors' affectations; but every bit as essential to the social personality is the messy, unaffected, unself-conscious "backstage" which complements and supports the staged action.

In North American neighborhoods the presentational front is usually the side which faces the street, but the example of Wildwood Park suggests that this formal scenographic landscape may develop opposite the vehicular-accessed side of the house if there is something on that opposite side worth belonging to or suitable for a "performance"that is, a properly constructed and well-maintained front stage. Correspondingly, such a neighborhood will tend to develop a complementary informal backstage landscape on the opposite side of the house, if room for such is available. In standardissue, front-loaded suburbs, this is always the back yard, and that back yard is typically a landscape tucked away out of the common realm and for the most part inaccessible (visually or otherwise) to anyone other than those who dwell in the house..$^{35}$ In Wildwood Park, this informal landscape is distributed all along both edges of each looping lane; it is not tucked away out of view, and so it is a landscape which "participates" in everyday community life (Figure 15). To continue the dramaturgical metaphor, Wildwood Park could be likened to the experimental theater form which intentionally reveals the backstage and the actions/events that normally take place out of the view of the audience-but this is an audience, it must be emphasized, which is composed almost exclusively of fellow performers. In Wildwood Park, the backstage lane-scapes are the most socially interactive landscapes, even more so than the park, which these days tends to be viewed through the picture windows more often than it is actively inhabited by residents.

Radburn's narrower lanes (Figure 6) are (and always have been) the site of social interactions as well. In spite of the front/back ambiguity inherent in the Radburn concept, Radburn residents report that one might encounter "anybody" within Radburn's park and connecting pathways, but typically one encounters only neighbors in the lane-scape. The lanes are activated socially by the simple process of routine arrival and departure to and from the home, ${ }^{36}$ and in spite of the minimal area afforded they tend to attract resident children who sometimes prefer the paved surfaces to the grassy expanse of the park. Radburn kitchens face the lanes just as they do at Wildwood Park, and the "eyes" on the lane through kitchen windows is a reason for Radburn parents to cautiously approve of the lanes as playscapes. As noted, however, the relative lack of space constrains the sort of uses, practices, and incidental landscape modifications plainly evident along Wildwood Park lanes.

The Wildwood Park lane (Figure 7) can be said to be a successfully updated elaboration of the Radburn lane-both because it accommodates more resident and visitor parking, ${ }^{37}$ and because it is enlivened by a more complex and active perimeter of diverse back yards. It has everything going for it that new urbanists hope to achieve on their hypothetical "livable streets" in terms of community life, but no self-respecting new urbanist would appreciate or endorse these lanes as proper streetscapes. As noted, these lanes exist on the informal, unpretentious back side of residences, and hence they have much in common with traditional back-alleys (Figure 16), which new urbanists value primarily for their service- 


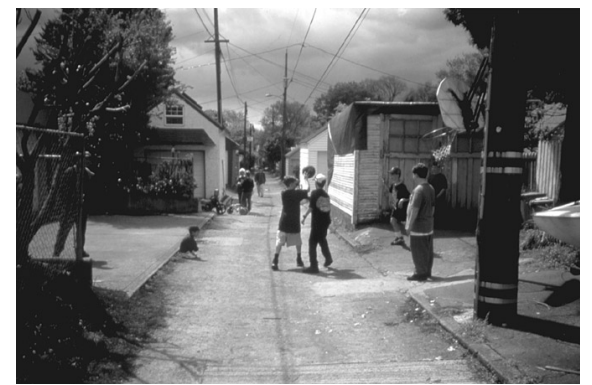

Figure 16. The highly interactive archaic back-alley as essential neighborhood social and recreational interior domain: Ladd's Addition, Portland, Oregon. (Photo by author.)

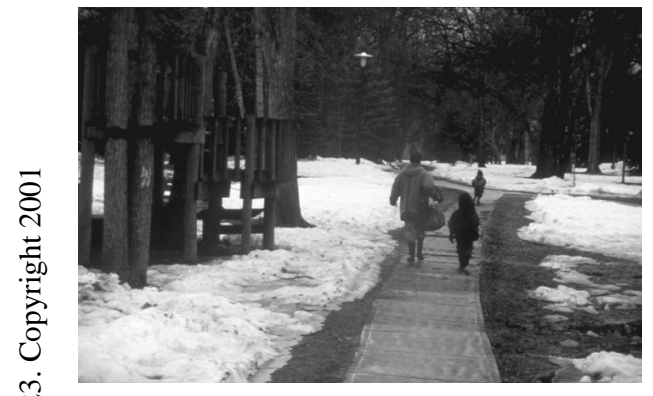

Figure 17. The pedestrian corridor through Wildwood Park's front-side landscape, shared by residents and visitors. (Photo by author.)

accommodation potential (Fulton 1997). Like back-alleys, Wildwood Park lanes are neither orderly nor are they truly public. ${ }^{38}$ If they had to be regulated and maintained so as to approach the new urbanist aesthetic ideal of the classic neighborhood streetscape, or if they were situated in the neighborhood in such a manner that they invited "outsider" traffic, they would surely have become different places than they are today. As they exist, they constitute vital neighborhood "defensible" space (Newman 1969). It must be strongly emphasized that this defensibleness is an aspect that derives from both the lanes' safe connection to the home landscapes and from the lack of any real gesture toward a civic ideal of publicness.

\section{Addressing the World Beyond the Neighborhood}

Of course, Wildwood Park is

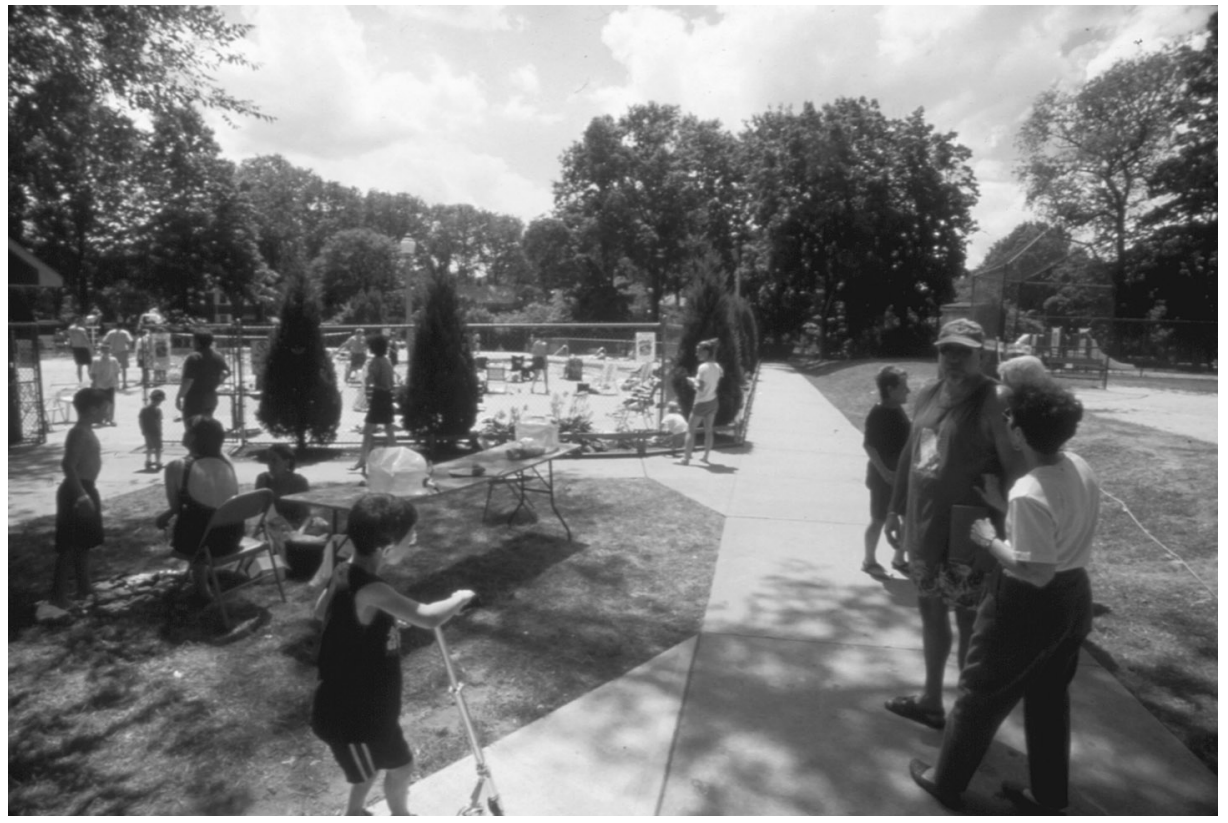

Figure 18. Radburn "Family Day", August 2000. On this occasion activities are centered in the main recreation area, but range throughout the extensive interior open space. (Photo by author.)

not an island, and there must be some consideration for its relationship to the world beyond. In practice Wildwood Park's public threshold is the perimeter of the superblock, just as at Radburn. Here we encounter the visitor's convenience dilemma; the stranger or tourist can park his or her car along the perimeter lanecollector road, and then choose to either approach residences through the formal front landscape of the park (Figure 17), or alternatively to wander on foot along the intimate lanes. Either way, such a visitor is likely soon to be noticed ${ }^{39}$ as an outsider, as not being one of the recognizable "familiar few" (Lynch 1990) who inhabit either connective space on a regular basis. Convenience for visitors is what Wildwood Park, like Radburn, sacrifices for the sake of security.

Wildwood Park draws the civicinterface line well beyond the intimate realm of routine family home life, a condition which can be read as exclusionary. It is certainly not gated, but it is nevertheless inherently protective in its general orientation, as is Radburn. To argue that Wildwood Park or Radburn is a model worthy of consideration for informing contemporary neighborhood design is to dismiss the new urbanist notion that this protectiveness constitutes a social pathology, and to refute the apparent new urbanist assumption that neighborhood scale and concern for a neighborhood's "inner life" (as opposed to its broader civic life) are not a consideration in establishing neighborhood cohesion, neighborhood identity, and supportive relationships among neighbors.

One Radburn couple, who have been residents of Radburn since 1949, provided a particularly insightful perspective on their neighborhood's evolution as a social landscape over the past half-century. As second-generation Radburnites (they are the second owners of their home, having moved in during the year of Radburn's twentieth anniversary), they have always lived among neighbors of diverse ages, and note that the landscape has always strongly supported a broad diversity of both planned and incidental communal 
activities, irrespective of demographic mix. They say that the neighborhood itself has proved through the years to be structured in a way that "facilitates friendships"- the lane for immediate neighbors, and the park for the community at large. This couple, who like many of their neighbors have raised children at Radburn, stress the tremendous significance of the open space structure in establishing a safe, useful, complex, and explorable inter-connective landscape for the interactions of children, which in turn has routinely fostered social connections among their parents throughout the community.

This landscape-as-meetingground condition has persisted in contemporary times, even now that the activities of resident children are more often focused on recreational and extracurricular events that occur outside the neighborhood (and to which they must be chauffeured by parents). The Radburn Association no longer sponsors the extent of neighborhood recreation programs that were established when the neighborhood was new (Hudson 1934), but informal, incidental recreational and social use of the common spaces (along with periodic planned community events such as the annual Radburn "Family Day" in August, which the author witnessed in 2000) continue to activate the community socially (Figure 18) and to underscore Radburn's identity as a place to which its residents "belong."

The long-term resident couple interviewed acknowledged many changes over the past fifty years, but at the same time found it "comforting" that during their tenancy Radburn has not undergone dramatic landscape change, as has occurred in the surrounding neighborhoods of Fair Lawn. The couple perceives Radburn as a sort of social oasis; in fact they used to worry that growing up in Radburn would leave their children unprepared for eventual life in the world beyond. What actually occurred, they related, was that their children became well adjusted socially, which they attribute in part to their children's socialization among a large and relatively diverse neighborhood contingent. They also noted that each of their adult children, who long ago moved away to establish professional and family life in other cities, has sought to establish residency in a Radburn-like neighborhood context-but each has yet to find this circumstance elsewhere.

Both partners in this couple are now retired, and note that Radburn is an excellent environment for retirees because of that same extensive and inter-connected interior landscape, and because of the accessible bus system which serves Fair Lawn. While the proportion of elderly and childless residents appears to have increased in recent years, the community is still home to a significant number of young children, such that their noisy presence remains very much in evidence (Figure 19) — but this is not a conflict (according to interviewees), because of the scale and arrangement of the common spaces, but also because Radburnites are conditioned to be "accepting" of their diverse neighbors. ${ }^{40}$

With respect to the issue of diversity, it must be noted that home values have recently appreciated considerably at Radburn. The couple who paid $\$ 12,500$ for their Radburn home in 1949 could now sell it for around $\$ 325,000$; another resident who paid $\$ 48,500$ in 1973 could find a market for her home in the range of $\$ 250,000-\$ 275,000$. The least expensive owner-occupied homes in Radburn today are townhouses which are valued at about $\$ 200,000$, and a few of the larger, extensively internally modernized park-facing homes could bring close to $\$ 500,000 .{ }^{41}$ This sudden appreciation is part of a rapidly escalating trend for values of homes within easy commuting distance from Manhattan, which lies only about sixteen miles to the east and is readily accessible by car, rail, or bus. In spite of this escalation in value and the exclusiveness it implies, at the present time Radburn's residents include a range of lower middle- to middle-income families and individuals.

Wildwood Park has witnessed a somewhat less-dramatic escalation of home values, but the neighborhood enjoys a similar local reputation as an enclave whose property values are enhanced significantly by the presence of its inter-connected interior park. In Wildwood Park, there seems to be a greater range of home valuations, probably because there are far fewer rigid architectural controls on modifications to the homes. In Radburn, the trustees of the Radburn Association (an elected body of fifty-two individuals, thirty-eight of whom are Radburn residents), have established regulations which generally proscribe radical transformations of home exteriors. The most common form of remodeling at Radburn is interior upgrading, enclosure of frontyard and side-yard porches, and con-

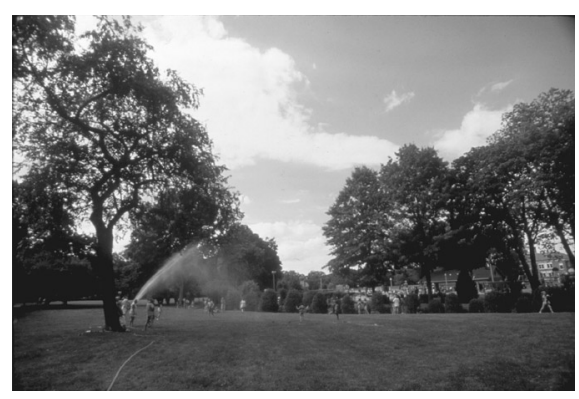

Figure 19. Although the overall resident population has aged and nowadays many extracurricular/recreational youth activities occur beyond the confines of the neighborhood, children remain a significant presence in Radburn's landscape. (Photo by author.)

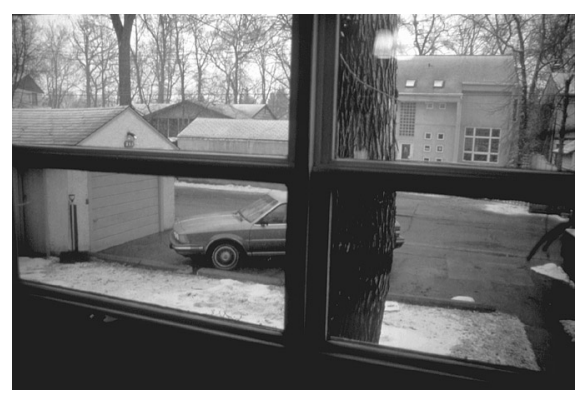

Figure 20. View through a Wildwood Park lane-facing window into a backyard. Note the substantially enlarged and reconstructed home visible in the background, across the lane. (Photo by author.) 
version of garages. ${ }^{42}$ In contrast, Wildwood Park features several examples of homes that have been extensively modified, some to the point that they appear to be replacements for the original structure. In Wildwood Park, one occasionally encounters an inconspicuous wood-sided one-story 1948-era prefabricated home of less than 1000 square feet standing adjacent to a very contemporary 1990s two-and-a-half story stucco-finished home of perhaps 3000 square feet (Figure 20). The incidence of this sort of extensive remodeling at Wildwood Park can be attributed to both the neighborhood's more libertarian covenants and to the local reputation that the neighborhood enjoys. Some of these remodels were undertaken by new residents, but reportedly (Nelson and Crockett 1984) many were accomplished by long-term residents who needed to significantly upgrade or increase the size of their home, but strongly desired to "stay put" in Wildwood Park because of the unique qualities of the neighborhood. Like the children of the Radburn couple mentioned above, these Wildwood Park residents were not finding anything comparable to their beloved neighborhood in the world beyond.

Both Radburn and Wildwood Park have a thoroughly middle-class heritage-Wildwood Park originally as pure "starter" homes ${ }^{43}$ and Radburn initially serving a slightly higherincome level. Although each neighborhood presently sustains a demographically diverse population, that condition is of course imperiled by escalating real estate values, and demographic diversity may eventually become a victim of the neighborhoods' notable qualities-a phenomenon encountered in all developments that achieve success in the real-estate marketplace, even new urbanist examples. Unquestionably, however, both neighborhoods have over several decades of evolution proven to be viable and, to varying degrees, adaptable community forms. Within their respective suburban contexts, both neighborhoods enjoy an unusually powerful sense of community identity, the foundation of which is the landscape which constituted the organizing principle for each. However, Wildwood Park has more successfully adapted to the twentyfirst century culture of automobility, and in so doing it stands as an exemplary model for a contemporary understanding of the relationship between neighborhood form and neighborhood social dynamics.

\section{Conclusion: Implications for Contemporary Planning}

Stein's admitted miscalculation was in imagining that he could effectively separate people and cars simply by providing an ample and attractive haven from cars. Radburn itself proved not only that this was unrealistic, but that people and cars could indeed interact safely in particular circumstances (Eubank-Ahrens 1991). ${ }^{44}$ Wildwood Park provides corroboration for the possibility of safe pedestrian/vehicular interaction, and beyond that demonstrates how the Radburn design parameters can be adjusted in such a way that the scope of available community space is both expanded and diversified. If Radburn's great success was the achievement of protection for children, Wildwood Park's was the enhanced socialization of the lane as a significant community landscape.

The Radburn lane, as noted, is the setting for regular social activity, but activity that is most often occasioned by arrival and departure; the Radburn lane is a true "node," in Kevin Lynch terms (Lynch 1960). However, the Radburn lane is not so much a place to be in its own right, because of the paucity of useful or adaptable space between homes and lane; of necessity the lane is primarily dedicated to car storage (Figure 21). Although there are significant mature trees established intermittently in the gaps between driveways, contributing to Radburn's overall parklike atmosphere, the general lack of backyard space dictates a rather straightforward, non-complex, unlayered quality. The house façades invariably predominate, as they stand quite close to the lane's edge. One interviewee at Radburn noted that in the 1960s and 1970s, some residents personalized their homes by painting them bright colors. This was not much of an issue on the park side of the homes, where spaces are much more generous and where Cautley's plantings intervened, but on the relatively intimate Radburn lane the effect could be overwhelming. The more recent trend, corresponding to both more conservative architectural styles and higher home market value, has been toward homogeneity of the lane-scape through compatible paint schemes and a regularized, wellmaintained ornamental foundation planting treatment. All of this underscores the importance of the Radburn lane as a community space, but

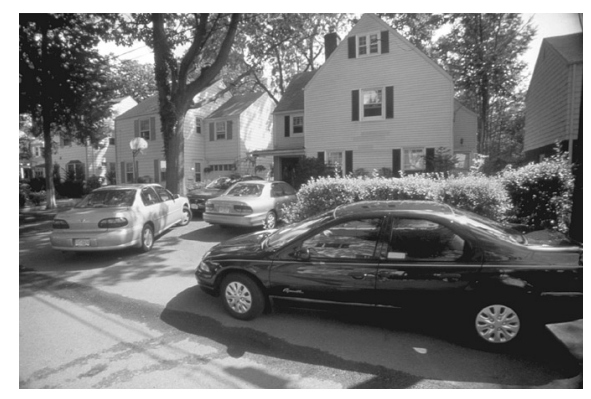

Figure 21. Car storage predominates in the Radburn lane-scape. (Photo by author.)

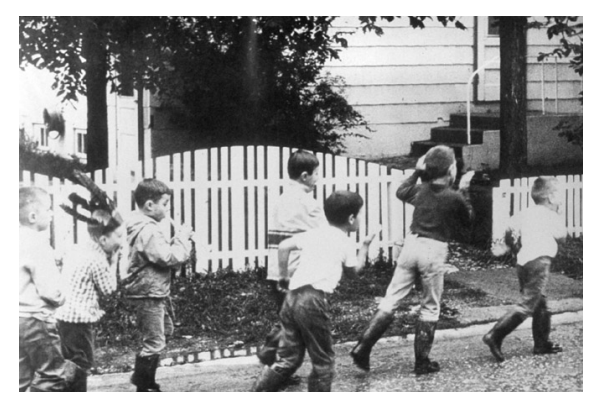

Figure 22. The Wildwood Park lanescapes are the "backstage" setting for a variety of incidental neighborhood activities. Despite the presence of moving and stationary cars, the lanes have always been considered safe play space for resident children. (Photo ca. 1974 by Siegfried Toews, and used with his permission.) 
also militates against a diverse or expressive landscape character.

In contrast, the "social" lane is embedded within Wildwood Parkembedded within its very landscape, and not just serving as an access conduit among the dominating back façades of the homes-and this lane is continually activated by a great diversity of things happening routinely along its edges (Figure 22). As with Radburn there are many resident "eyes" on the lane, through windows perforating the backs of the homes, but also "eyes" from the active lanefacing back yards themselves. The Wildwood Park lane of course carries traffic-more traffic than a Radburn lane, due to its looped form and the greater number of homes served by each lane (Figure. 5) - but almost exclusively this intermittent traffic consists of residents or their visiting acquaintances. As a result, vehicle operators are generally respectful of normative neighborhood driving and parking conventions-just as is the case at Radburn. In contrast with the lack of control exercised over the Wildwood Park lane's aesthetic character, there is a powerful degree of control exercised over the way the lane "works" as an integrative community landscape.

In a truly public/civic venue as sanctioned by new urbanists, this control could not be maintained because of increased traffic flow, more likely and more frequent violations of traffic norms by outsiders, and the uncertainty posed merely by the presence of a greater number of nonresidents, whether intruding in vehicles or as pedestrians. The lane's social dynamism is clearly a product of its internality. If we accept the internal lane as a possible model for the contemporary neighborhood street, we could then reflect on issues that are presently of concern to residents of Wildwood Park in order to understand how the concept could be further elaborated to meet twentyfirst century needs. (As noted previously, the residents-only internal street is antithetical to the street-aspublic/civic-realm precept of new urbanism; it is ironic to discover that at Seaside, the prototypical new urbanist village, management found it nec- essary after the fact to exclude "outsider" automobile traffic by posting signage [Figure 23] that prohibits all but resident automobile traffic upon residential streets) ${ }^{45}$ (Audirac and Shermyen 1994).

There are two possible refinements to the Wildwood Park scheme which are suggested by both observation and anecdotal information obtained from residents. The first addresses the general issue of visitor access to homes. As noted earlier, GBR designed Wildwood Park's Radburn-style plan with the presumption that outside visitors would leave their vehicles along the perimeter of the superblock and proceed on foot through the park which constitutes the front yard landscape, in order to approach homes at their front doors. The problem with this presumption is not simply that visitors expect to park directly at or very close to the house they are visiting (as they may do when visiting almost any other low-density housing community); there is also nothing the visitor encounters in the landscape that makes it explicit that this is the preferred practice for outsiders-nor are there "wayfinding" aids that could help guide the visitor through the labyrinthine park (Figures 24 and 3) once the visitor begins to seek the front door on foot. While it admittedly is a substantial challenge to redirect customary and normative parking and access practices for visitors, this is a design issue that certainly could be addressed more thoughtfully than has been done at Wildwood Park or even at Radburn.

The second proposed refinement addresses the one "glitch" in the site plan of Wildwood Park about which a number of residents express dissatisfaction. The ten looped lanes vary in their alignment, but most are essentially three-sided, featuring two relatively sharp corners (Figures 25 and 5) at the two internal vertices. This creates a conundrum similar to one encountered in the design of suburban cul-de-sacs for access to smaller single-family lots. Wildwood

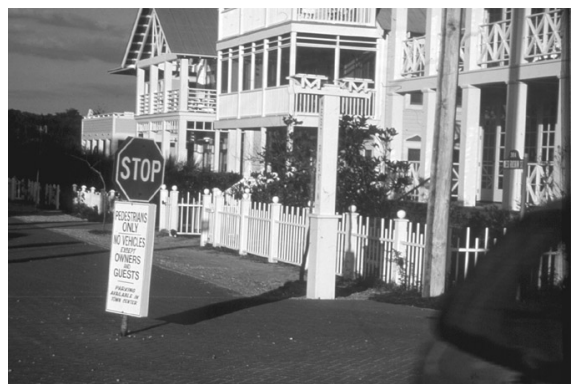

Figure 23. Ex-post-facto restriction of access by visitor automobiles within the residential blocks of Seaside, Florida. (Photo by author.)

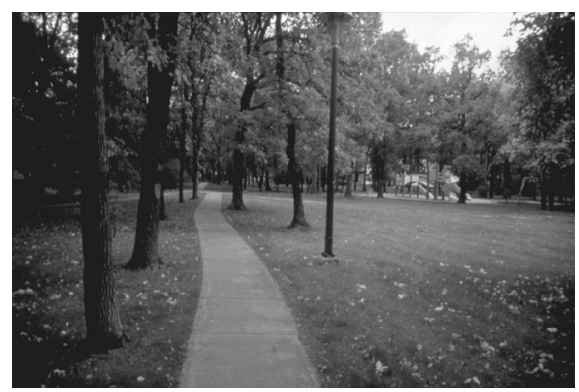

Figure 24. A walk in the park through the expansive interior open space among front yards in Wildwood Park. As at Radburn, Wildwood Park's open space contains a scattering of recreational facilities for common use. (Photo by author.)

Park lots which are situated on the outside of the lane corners have greatly reduced lane frontage, and this in turn creates an inequitable distribution of available lane-edge parking spaces. Unlike those who reside along straight stretches of the lanes, an outside-corner lot dweller is hard-pressed to accommodate parking within his or her lot. Also, because the outside-corner lot's narrow frontage must be wholly dedicated to its own driveway's access, these residents have no abutting lane-edge parking space. As the average number of cars stored per residence has increased through the years, ${ }^{46}$ this condition has generated occasional territorial friction among residents. While there is no apparent remedy for this problem at Wildwood Park, the contemporary designer might reconsider either lane geometry or lot 


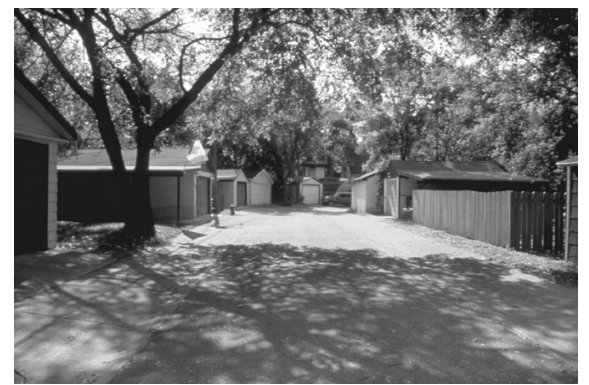

Figure 25. A Wildwood Park lane-scape in early autumn. Note the densification of garages in the background, on the outside corner of the looped lane. Outside-corner lots have reduced lane frontage, which exacerbates lane-edge parking territorial issues. (Photo by author.)

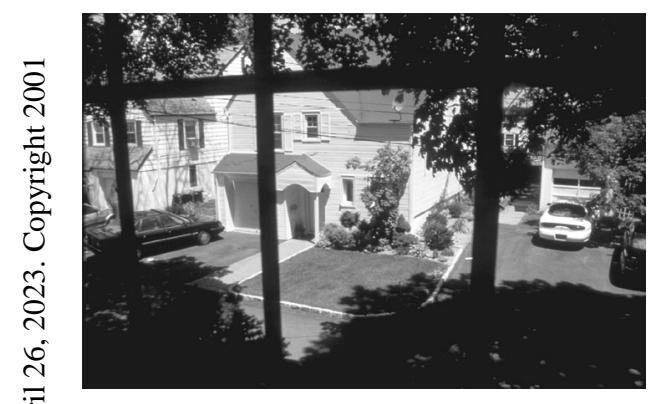

Figure 26. The Radburn lane-scape as viewed through a second-story window. Note single-car garages and limited available parking space, a condition exacerbated by the widespread conversion of Radburn garages to nongarage use. (Photo by author.)

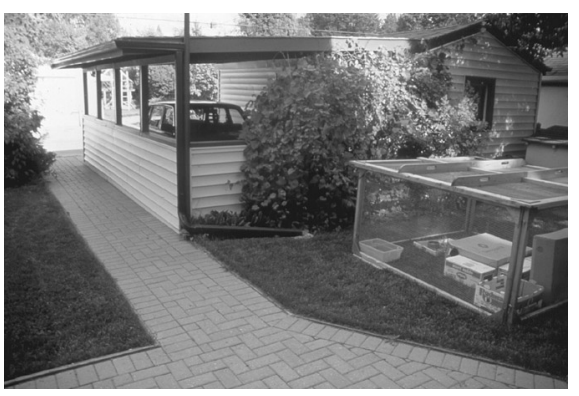

Figure 27. A rabbit hutch stashed out of view in a Wildwood Park backyard, within the happenstance, intimate, and very useful space which occurs between the home and the detached garage (the garage having been built several years after the home was constructed). View is from back door stoop. (Photo by author.) pattern (or both) in order to preclude this reduced-frontage dilemma. For most Wildwood Park residents, there is at least adequate resident parking available. The typical condition at Radburn is somewhat more acute (Figure 21). One Radburn resident noted that the four households located on his lane's hammerhead own a collective total of seven cars-fewer than two per household-but the confined space and tight geometry of the paving necessitates a considerable amount of "jockeying" of cars which inevitably block each other in place.

Another "convenience" issue worth noting, and well worth considering for contemporary development is one that has powerful implications for the lane-scape. Radburn's garages $^{47}$ are, like those of most contemporary houses, integrated with the house proper (Figure 26). This constitutes a great convenience for residents, and is certainly of significant benefit during cold or wet weather periods or during times of heavy snow accumulation, as happens intermittently in New Jersey and routinely in southern Manitoba. The reason Wildwood Park garages are detached is because they are not part of the original house construction; the houses were constructed as cheaply as possible, but Hubert Bird and GBR left sufficient rear yard space to make possible the addition of garages later as an option for residents. What is most apparent to the observer of the Wildwood Park lane today is that the detached garage is an essential structuring component of the lane-side yard. In many cases, residents have found the essentially private "pocket" that is formed by the space between the house and its detached garage to be a useful, highly adaptable and intimate space (Figure 27). This is where one will find many examples of personal outdoor-use structures (patios, low decks, seating/lounging furniture, etc.) for activities that are more comfortably conducted at a slight remove from the public interface with the lane's edge. For residents who tend to maintain relatively tidy yards, it may be the place for storage of things that they would like to conceal from plain view, such as tool sheds, dog runs, or trash receptacles. These are fortuitous but essential spaces-in effect, they constitute the mitigating factor that allows the Wildwood Park resident to mediate his or her backyard landscape between its dual role as both private outdoor realm and active "member" of the social lanescape.

Wayfinding and isolated parking issues notwithstanding, Wildwood Park has firmly established its viability as a community landscape. Its matched set of complementary, integrative landscapes work in concert to sustain a powerful community focus-the park for the community as a whole, and each lane for its respective section.

The success of its adaptation and elaboration of the seventy-year-old Radburn model challenges contemporary new urbanist assumptions about publicly oriented streetscapes and reaffirms the wisdom and pragmatism intrinsic to Clarence Stein's radical "garden-neighborhood" community experiment.

Even so, it is no more appropriate to extol the Radburn plan (and its later elaborations) over all other possible neighborhood conformations than it is to present new urbanist principles as a universal solution, as appears to be suggested by new urbanist rhetoric and by surprisingly incomplete reference sources such as Architectural Graphic Standards. Different neighborhood schemes suit different populations and demographic groups, and their patterns are deeply connected with historical trends and with the patterns of human behavior. Radburn and Wildwood Park represent one particular landscape mutation that developed in thoughtful and innovative response to significant social and cultural forces of the twentieth century; as such, these landscapes merit attention and further study by innovative planners of the twenty-first century. 


\section{Acknowledgments}

The author wishes to express his sincere appreciation for the invaluable contributions to this effort by Louise Orlando, Jean and Dan Rothermel, Carl Nelson, Ted McLachlan, Barrie and Phyllis Webster, and the great number of hospitable residents at both Radburn and Wildwood Park who offered their unique insights and gave very generously of their time.

\section{Notes}

1. Stein and Wright were both educated in architecture, but Stein practiced primarily as a community planner/town planner while Wright practiced as a planner/landscape architect. Stein biographer Kermit Parsons notes that at Radburn, "Stein's architectural and community planning skills were combined with Wright's site-design talent to invent and apply a totally new approach to community design, which Stein called 'a revolution in planning." (Parsons, p. 106)

2. The towns of Letchworth and Welwyn and the Hampstead Garden Suburb are the important English prototypes. Stein and Wright traveled together to England and Europe to study emerging garden city prototypes in 1924 , just prior to their collaboration on the design for the Sunnyside Gardens housing project in the New York City borough of Queens. Stein and Wright experimented with site planning innovations at Sunnyside Gardens, "an experimental low-density project of twelve-hundred houses with shared inner courtyards" (Parsons, p. 651) which were subsequently refined at lower-density Radburn.

3. The RPAA was the Regional Planning Association of America, a New York City-based atelier comprised of "architects, economists, social reformers, community designers, urban critics, and writers" (Parsons, p. 104) a group whose intellectual leader was Lewis Mumford and of which Clarence Stein, Henry Wright, Benton MacKaye, Charles Stern Ascher, and Frederick Ackerman (among others) were members, along with philanthropist/real estate developer A. M. Bing. In 1924 Bing established the City Housing Corporation (CHC), which financed and developed both Sunnyside Gardens and Radburn. Parsons notes that New York City of the 1920s was "a cauldron of intellectual ferment, rich in literary, artistic, and architectural innovation." (Parsons, p. 107) The RPAA sought to establish the garden city concept as a planning force in America.

4. The three constructed Greenbelt Towns included Greenbelt, Maryland; Greendale, Wisconsin; and Greenhills, Ohio. A fourth Greenbelt Town-Greenbrook, New Jersey-was never built due to opposition from adjacent landowners.

5. Columbia (MD), Reston (VA), Jonathan $(\mathrm{MN})$, Peachtree City (GA), and Irvine (CA) are examples of the American New Towns which began development in the 1960s. The Woodlands, near Houston (TX), represents the New Town concept evolved as an "ecoburb", in which ecological planning was a foundation for community structure. There are a great variety of publications which describe and detail New Town planning philosophy and which pay tribute to Radburn as inspiration. Good references for New Towns planning strategies include: James Bailey New Towns in America: The Design and Development Process (New York: John Wiley and Sons, 1973) also Gideon Golany and Daniel Walden, 1974. The Contemporary New Communities Movement in the United States (Urbana: University of Illinois Press, 1974). A work that captures the spirit of the movement's optimism is Carlos C. Campbell. New Towns: Another Way to Live (Reston, Virginia: Reston Publishing Co. Ltd., 1970). For a retrospective view of the development process for one New Town example, see Tennenbaum's Creating a New City: Columbia, Mary land (1996).

6. For detailed information on Village Homes and evidence of Radburn's influence upon its plan, see Corbett and Corbett 2000 and Corbett 1981. Village Homes makes many other appearances in the literature; see Girling and Helphand's 1994 Yard Street Park for a recent example.

7. Schaffer's book is the most comprehensive retrospective of Radburn to date. See Girling and Helphand's 1994 Yard Street Park for a concise contextualization of Radburn in openspace planning history, as well as for further references to Radburn in the literature.

8 . There are several publications from the past decade which establish new urbanism's precepts; the most comprehensive and systematic reference being Leccese and McCormick's 1999 Charter of the New Urbanism.

9. For a recent perspective on Jacobs' antigarden city orientation, see Malcolm Gladwell's "Designs for Working: The Science of Offices Moves beyond the Cubicle" in The New Yorker, Dec. 11, 2000, pp. 60-70. Gladwell notes that Jacobs "hated" Stein's Chatham Village (in Pittsburgh) for its "lack of sidewalk life"; so enamored was she of the rich and complex daily social life of her hometown Greenwich Village (in Manhattan), and so convinced was she that this represented the urban ideal for all, that she "wasn't concerned that some people might not want an active street life in their neighborhood" (p. 70).

10. Calthorpe faults garden city designs initially on functional grounds, noting that they retained "fundamental modernist principles: segregation of use, love of the auto, and dominance of private over public space. In these utopias, the street as the community's habitable ground disintegrated." He then faults their aesthetics: "The next generation of new towns should learn from these failures, avoiding their sterile and suburban character." (p. 33)

11. "As reproduced indiscriminately throughout the western world for the past century," says Krieger, "the garden suburb ceased to even attempt to simulate the physical organization of a town, much less to host its social and political structures." (p. 13)

12. New urbanist guidelines often call for parallel parking along community streets, claiming that the line of cars along a street establishes a protective "wall" or barrier between sidewalks and streets. Whether this "wall" constitutes a protective barrier or-since the "wall" has small gaps between cars which short but very mobile young children might on occasion dart through into the path of a surprised motorist-an actual streetscape hazard, remains a serious question. Like many other new urbanist behavioral truisms, this presumption is grounded more upon conjecture than upon empirical evidence-and it is a presumption peculiarly lacking in any thoughtful consideration for the welfare of children. What new urbanists actually do know, and what is the actual aesthetic basis of their affinity for on-street parking, is that street parking can obviate both on-site parking and driveways, which of necessity cut across the pedestrian realm of the sidewalk and allow the car to invade the front yard. In any case, it is striking how often drawings of streetscape views used as promotional illustrations for proposed new urbanist developments (Figure 2 is an example) completely eliminate cars from the picture, even cars parked along streets.

13. "Dink", a neologistic acronym meaning "double income, no kids" was coined to describe the growing demographic family group comprised of couples who defer having children while both work full time.

14. According to Radburn Association manager Louise Orlando, there have been no pedestrian traffic fatalities on a Radburn lane in its 80 +-year history.

15. Planned unit developments emerged as a popular planning phenomenon in the U.S. in the 1970 s, as an alternative to single-use zoning. PUD classification allowed developers to zone their projects to a specific land-use plan which typically included a variety of housing types as well as non-residential land uses, such as neighborhood commercial and connective open-space. For a description and brief history of PUDs see Frederick Jarvis's 1993 site planning manual.

16. Figure 1 portrays the extent of Radburn asbuilt compared with the master plan. Of eight superblocks proposed, only the two superblocks presently known as "A" and "B", along with two isolated cul-de-sacs (located within a never-realized third superblock to the south) were actually constructed. Note, however, that Radburn as-built does contain the elementary school and the community's primary recreational-use node, both of which would have been accessible to the entire development via grade-separated pedestrian paths had the project been fully developed. 17. Or, more precisely, "live-end" back alleys, in the parlance of planner/architect Mark Childs. See his 1996 article "The Living End", pp. 14-15. Childs differentiates the innovative "live-end" cul-de-sac-a cul-de-sac which provides for a pedestrian pathway connection continuing beyond its terminus, from a "deadend" cul-de-sac, which provides no such pathway. Radburn lanes are perhaps the origi- 
nal live-end cul-de-sacs, as they feature narrow walkways which thread between the homes which are situated on the hammerheads, and these narrow walkways (Figure 28) connect with the pathways (Figure 29) which in turn connect with Radburn's park.

18. In his introduction to the 1956 edition of Stein's Toward New Towns for America, Lewis Mumford extolled the virtues of the superblock: “. . .the super-block, with entrant cul-desacs ... (t) his admirable device for lowering road costs, increasing the amount of green space, and creating tranquil domestic quarters free from through traffic."

19. Radburn today features one gradeseparated crossing, in which a pedestrian path tunnels under Howard Avenue (Figure 30), the road which separates its "A" and "B" superblocks. Stein cites Olmsted's Central Park in Manhattan (through which he habitually strolled while living in New York City) as the inspiration for this feature. There was also formerly a wooden pedestrian bridge leading to the south over Fair Lawn Avenue, since demolished. These crossings were intended for use by anyone, but their essential purpose was for the safe passage of Radburn children walking or riding bikes to school.

20. The "partial" Radburn legacy can be discerned in a great variety of subsequently developed housing projects which link the back yards of residences by means of accessible pedestrian open space. See, for instance, the author's 1999 "Open-back Neighborhoods". 21. This article provides a historical review of the development and transformation of Wildwood Park's landscapes over fifty years. Pursuant to the historical study, the author conducted extended field work at the neighborhood which included observation, mapping, resident "focused interviews" and a follow-up survey; the interview and survey questions explored the residents' perceptions of neighborhood landscape issues and their habitual uses of the differentiated neighborhood landscapes over the period of their tenure as residents. The author's generalizations which appear in this paper concerning landscape issues, conditions, resident/visitor behaviors, attitudes, etc. are drawn primarily from information gathered during extended visits to Wildwood Park in two different seasons, but also have basis in similar studies conducted at Wildwood Park in the 1970s (see references for Mubanga, Toews and

Nelson/Crockett research reports).

22. During a recent visit to Radburn, the author was given a guided tour through the community as the guest of the manager of the Radburn Association. The tour encompassed the lanes, the open space network, and several residents' properties and homes. On other occasions during this visit the author made general behavioral observations, conducted selective field mapping of front- and back-yard landscapes, and had the opportunity to conduct extended interviews with the manager and several residents or resident families. As with the Wildwood Park study (see previous note), the interview questions explored the residents' perceptions of neighborhood landscape issues and their habitual uses of the differentiated neighborhood landscapes over the period of their tenure as residents. The author's generalizations about landscape issues, conditions, resident/visitor behaviors, attitudes, etc. are drawn primarily from information gathered during this visit.

23. The CMHC (Canadian Mortgage Housing Corporation) served the similar function of guaranteeing mortgages for veterans as did the VA (Veterans Administration) and the FHA (Federal Housing Administration) in the U.S.

24. Hubert Bird is reputed to have first become aware of Radburn when he observed it from an airplane window shortly after take-off from New York City in the 1930s. This possibly apocryphal story is recounted in both the Reimer and Nelson/Crockett Wildwood Park references.

25. On this point, the CHA reviewers noted: "Whereas this type [a hammerheads cul-de-sac termination] does result in a slight savings of pavement ... when one considers that the milkman, the bread man, the fire trucks, snow plows, as well as the individuals living in the houses will enter these cul-de-sacs, it becomes obvious that an easy method of turning around is necessary." (Nelson and Crockett, p. 41)

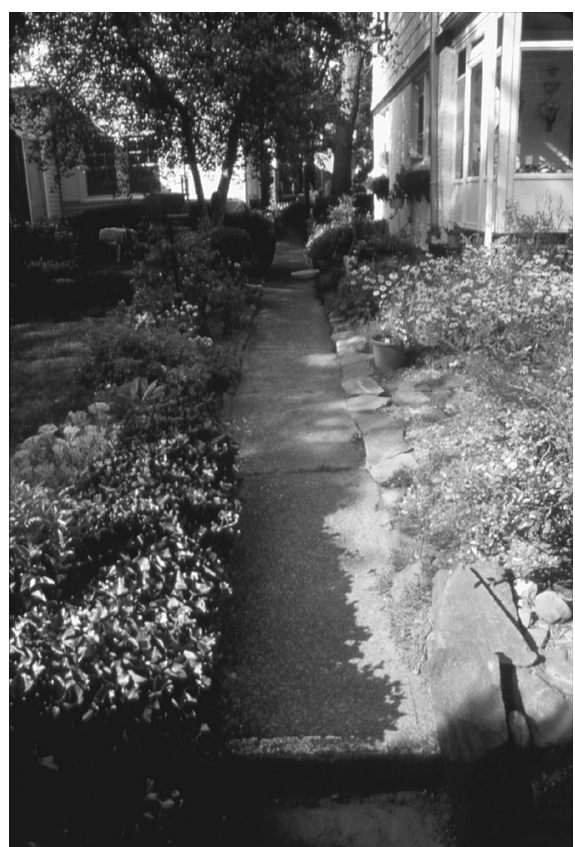

Figure 28. The "live-end" cul-de-sac: A typically narrow walkway threading between homes located on the hammerhead terminus of a Radburn lane-a walkway which connects with the inter-lane pathways, which in turn connect with Radburn's central interior open space. (Photo by author.)
26. Radburn cul-de-sac lanes and Wildwood Park looped-lanes vary in size (and alignment), but on average the Radburn lane serves about 18 homes, while on average the Wildwood Park lane serves 29. Considering only the lane and its lots (and not taking into account the common open space), density for

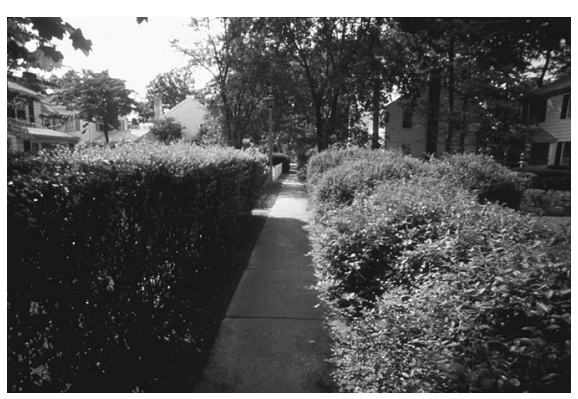

Figure 29. Cautley's hedges define the Radburn inter-lane pathways as pedestrian conduits; when the hedges are at or above eye-level, as is often the case, the front yards are hidden from public view. (Photo by author.)

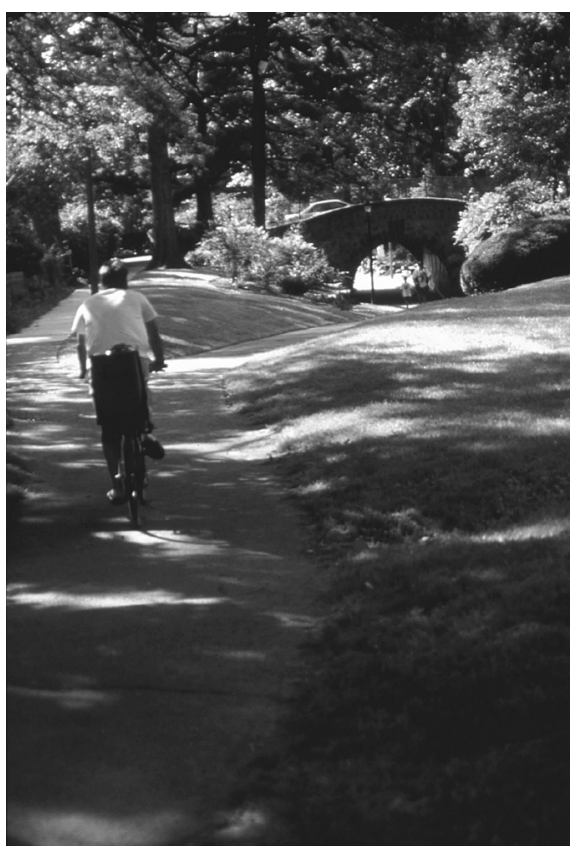

Figure 30. Radburn's famous pedestrian underpass, a tunnel under Howard Avenue which connects "A" park and "B" park. This design feature was directly inspired by Olmsted's similar gradeseparated crossings in Manhattan's Central Park, and Stein's tunnel inspired similar pedestrian-friendly constructions in 1960s American New Towns such as Columbia, Maryland. (Photo by author.) 
a typical Radburn lane is approximately 8.5 dwelling units per acre, and for Wildwood Park a similar measure yields a little over 5 dwelling units per acre. However, considering that Wildwood Park front yards, unlike Radburn front yards, are effectively part of the "park" because of the absence of privateproperty screening, one could subtract Wildwood Park front yards from the equation in order to produce a more comparable pair of figures; this adjustment yields an increased density figure of 6.7 dwelling units per acre for a typical Wildwood Park section. The fact that Radburn's density figure remains greater following this adjustment largely reflects the fact that Radburn's lots are narrower and Radburn includes some attached homes, while Wildwood Park does not.

27. Meyer coined the term "figured ground" to call attention to her point that landscape as experienced-a complex and protean environment-cannot be adequately described through static, plan-view illustration (see following note for elaboration).

28. Meyer uses the example of Radburn (among others) to highlight the limitations inherent in the abstraction of a "figure-ground" diagram, which represents landscape as a collection of solids (buildings and other large structures) and voids (non-buildings). She argues that this type of diagram is an oversimplification of the richness and complexities of the "figured ground" that actually constitutes landscape, and cautions that although it is often illustrated in texts as a figure-ground diagram, Radburn cannot be adequately represented or understood by means of such abstractions. Meyer also notes that planning texts, in their failure to either represent or acknowledge Radburn's figured ground, routinely ignore landscape architect Cautley's important contribution to the design and structure of the Radburn landscape. 29. Information gathered in resident interviews.

30. One resident couple noted that Radburn front yards can be "social" by choice-if residents choose to engage the park or connecting pathways, they construct outdoor frontyard seating areas which allow easy interaction by way of visual and proximal linkage to them. In their own case (their home is on a hammerhead and thereby abuts the park directly), their patio is situated close to the park's walkway, and the husband will sit facing the park when he is willing to interact with passers-by, but will turn his back to the outside when he wants to be left alone.

31. The Radburn Association's current manager (who has been a resident of Radburn since the early 1970s) has general responsibility for, among many other things, maintenance of neighborhood standards respecting the landscape interface between front yards and the interior park-like open space. She noted to this author that there is little concern for privatization screening along the pathways which separate adjoining cul-de-sacs, because these paths are considered to be merely pedestrian conduits leading from the perimeter streets into the park-and thus not really part of the park itself. The park itself, however, is perceived as a central community resource, and the maintenance of its visual relationship to the homes which directly surround it is a paramount concern for the community at large. Because of this, she occasionally finds it necessary to advise park-abutting residents to limit or control fences and vegetative screening along their properties. If necessary, she can cite the appropriate sections of "The Radburn Association Guidelines for Architectural Control". Section 9.11 limits fence heights "adjacent to walkways, paths, streets, and property lines" to thirty-six inches (p. 24); section 9.9 provides that "All hedges and shrubs shall be kept pruned and trimmed as seasonal growth occurs", and that "trees and shrubs shall be of a type which, upon maturity, shall be of a size compatible with their location. " (pp. 26-27) 32. The first generation of Wildwood Park residents were a demographically homogeneous group-nearly all were married couples with young children, and many (but not all) of the husbands were veterans who had recently returned from the war. Relatively few of these families owned automobiles in the late 1940s and $1950 \mathrm{~s}$, and so the pedestrian park tended to serve a more important social and connective role than it did in later years.

33. Wildwood Park zoning bylaw 1800 as amended September 20, 1984.

34 . In the $1950 \mathrm{~s}$, after observing the behavior patterns which had developed in Radburn over more than two decades, Stein noted that "The playgrounds, the central greens, and the swimming pools in summer, are the favorite recreation places for Radburn children. But the paved lanes are also used for playing. I have studied the reasons for this so that in the future we might keep children and autos apart to an even greater degree. We will never do so completely, nor do I think we should attempt to. The spirit of adventure should not be extinguished." (Stein 1956, p. 52)

35. Contemporary CCRs (codes, covenants and restrictions), which can be quite detailed and are often rigidly enforced, serve well to illustrate how homeowners value conformity and uniformity within the front-stage community landscape of the suburban street. This is partly an economic impulse-adherence to strict rules is seen as a means to maintain property values-but it is a cultural impulse as well. CCRs reinforce community identity by limiting freedom in the public realm of the street, but note that CCRs rarely concern the "informal" backstage landscape of the residential back yards-thus backyards in such neighborhoods reflect a much more libertarian character than the scrupulously controlled fronts.

36. This arrival/departure incidental social dynamic was reported on by several interviewees, and it mirrors similar activities characteristic of neighborhoods served by back-alleys. See the author's "Back-alleys as Community Landscape" for evidence of this in both historic and contemporary alley-based neighborhoods. 37. Figures 5 and 25 illustrate the lane-access and laneside parking dilemma for lots located on the outside corners at the bends in Wild- wood Park lanes. Inequities in lane-frontage width lead to a variety of problems, which could be addressed in future developments with a reconsideration of lane alignment. 38 . Back-alleys are typically public right-of-way, like streets, and thus in theory they are accessible to anyone; in practice, however, backalleys take on a semi-private status because of their intimate relationship with the informal landscape of the backyards which the alley serves.

39. When the author first visited Wildwood Park and began to walk around alone in its lanes, he was quickly noticed by a resident couple who were having tea on their backyard patio (Figure 31 ) and, in a very neighborly manner, asked how they could be of assistance to him. This couple, who as it happened later played host to the author during his three-day stay at Wildwood Park, related in a subsequent conversation that their interest in the sightseeing author (as with other unfamiliar individuals occasionally observed in the lanes) was meant to be both hospitable and cautionary. 40. The quality of this spirit of acceptingness was tested in the late 1980s, when the community suddenly became home to a large influx of immigrant families who had been relocated to live in the two Radburn apartment blocks (now known as "Eldorado Village") from the former Soviet Union. From anecdotal evidence gathered in a number of resident interviews, there were significant cultural dicontinuities immediately made evident, as the

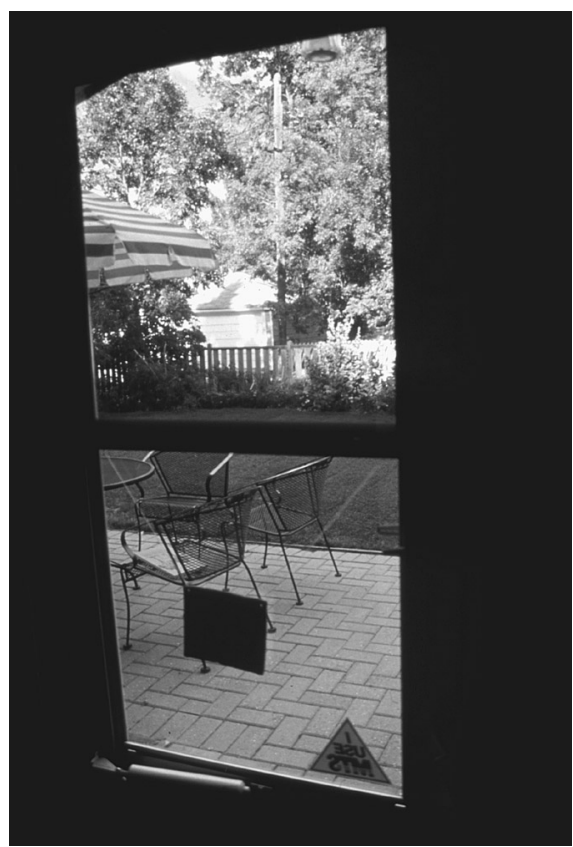

Figure 31. A view into the backyard, and to the lane just beyond, from a Wildwood Park kitchen door. The patio seen here was the site of the author's initial incidental contact with a Wildwood Park family. (Photo by author.) 
newcomers began to make social and recreational use of the common spaces; but instead of the ghettoization which might be expected to be inevitable in such a situation, the new residents soon became well-integrated with Radburn community life. Many of the "native" Radburnites took an active role in promoting various community social outreach activities and volunteered for language/literacy program instruction, all of which had the effect of overcoming the potential for division or mistrust between cultural factions. To the visitor walking around in Radburn today, the presence of the Russian neighbors is very much in evidence, but they seem as much a part of the neighborhood as their American-born neighbors.

41. Even so, Radburn is not the most upscale of neighborhoods in the immediate region. That designation belongs to Ridgewood, a nearby neighborhood with significantly larger homes (of greater average market value), larger lots, and an entirely conventional street network.

42. While Radburnites are free to convert their garage interiors to non-garage use, they are still required by neighborhood covenant to provide for out-of-sight storage of yard clutter. For this reason, a popular remodeling compromise at Radburn is a garage conversion which leaves the rearmost four feet of space as a shallow storage room (for bicycles, grills, plastic swimming pools, etc.) still accessible from the driveway through the garage door, and divided from the remainder of the converted garage room by an interior wall. 43. One of the most attractive attributes of the Wildwood Park home in 1948 was its relatively low cost, even for a starter home. Through the incorporation of a limited street system (originally, the lanes were not paved with asphalt) and the use of house prefabrication techniques, Bird was able to market his homes at a price about 15-20\% below comparable homes in more traditional developments (Nelson and Crockett, 1984)

44. The European "woonerf" ("living street") model offers another means to address the automobile/pedestrian dilemma, but the concept has not caught on in North America, perhaps due to the size and number of cars which typically inhabit American neighborhoods. This urban residential design approach, in which streets are contorted or intentionally obstructed as a "traffic-calming" strategy, seems to have met with the greatest acceptance in urban environments which feature much smaller numbers of much smaller cars (as in the Netherlands, Denmark, and Japan). 45. Audirac and Shermyen relate that ". . . in Seaside . . a all houses have front porches to provide a transition between the private and public realms. But many residents had allowed shrubs to grow and screen their porches from the street to obtain more privacy. A few residents also requested rear porches which would allow them to spend time overlooking their private backyards rather than the street in front of the house. A similar desire for privacy and security, along with a desire to protect property values, led Seaside residents to post signs on streets discouraging vehicles from passing through."
46. In the late 1940 s, only about one Wildwood Park family in ten owned an automobile, or three per section. By 1960, the average was approximately one car per household, or thirty per section; by the late 1990s, this average was over two cars per household, or sixty+ per section - a twenty-fold increase of car ownership and requisite storage capacity over a span of fifty years. The number and size of laneaccessed garages has, of course, grown accordingly, which has in turn transformed the character of the Wildwood Park lane-scape. (Approximations of car ownership figures based on author's observations as well as anecdotal information provided by long-term Wildwood Park residents during interviews.) 47. There are only two instances of detached garages in all of Radburn; typically, the Radburn house incorporates a single-car garage, the door for which faces the lane.

\section{References}

Audirac, Ivonne, and Anne H. Shermyen. 1994. "An Evaluation of Neotraditional Design's Social Prescription: Postmodern Placebo or Remedy for Suburban Malaise?" Journal of Planning Education and Research 13(3): 161-173.

Bacher, John C. 1993. Keeping to the Marketplace: The Evolution of Canadian Housing Policy. Kingston and Montreal: McGillQueens University Press.

Bayne, H. A., Town Planning Consultants. 1945 (amended 1984). Wildwood Park Town Planning Scheme (including zoning bylaws). Winnipeg: Municipality of Fort Garry.

Birch, Eugenie Ladner. 1980. "Radburn and the American Planning Movement: The Persistence of an Idea." Journal of the American Planning Association 46(4): 424-439.

Calthorpe, Peter. 1993. The Next American Metropolis. New York: Princeton Architectural Press.

Childs, Mark. 1996. "The Living End." Planning 62(5): 14-15.

Christensen, Carol A. 1986. The American Garden City and the New Towns Movement. Ann Arbor: UMI Research Press.

Corbett, Michael N. 1981. A Better Place to Live: New Designs for Tomorrow's Communities. Emmaus, PA: Rodale Press.

Corbett, Judy, and Michael Corbett. 2000. Designing Sustainable Communities: Learning from Village Homes. Washington, D.C.: Island Press.

Doucet, Michael and John Weaver. 1991. Housing the North American City. Montreal and Kingston: McGill-Queen's University Press.

Duany, Andres, Elizabeth Plater-Zyberk, and Jeff Speck. 2000. Suburban Nation: The
Rise of Sprawl and the Decline of the American Dream. New York: North Point Press.

Eubank-Ahrens, Brenda. 1991. "A Closer Look at the Users of Woonerven." Public Streets for Public Use. New York: Columbia University Press.

Filler, Martin. 1982. "Planning for a Better World: The Lasting Legacy of Clarence Stein." Architectural Record 170(10): 122127.

Fulton, William. 1997. The New Urbanism: Hope or Hype for American Communities? Cambridge, MA: The Lincoln Institute of Land Policy.

Girling, Cynthia, and Kenneth Helphand. 1994. Yard Street Park. New York: John Wiley and Sons.

Goffman, Erving. 1959. The Presentation of Self in Everyday Life. New York: Anchor Books.

1991. "Dramaturgical Theory." The Structure of Sociological Theory (fifth edition). Belmont, CA: Wadsworth Publishing Co.

Harris, Richard, and Peter J. Larkham (eds.) . 1999. Changing Suburbs: Foundation, Form and Function. London: $\mathrm{E}$ and $\mathrm{FN}$ Spon.

Hoke, John Ray, Jr. (editor-in-chief). 2000. Ramsey and Sleeper Architectural Graphic Standards (Tenth Edition). New York: John Wiley and Sons Inc.

Howard, Ebenezer. 1902. Garden Cities of Tomorrow (being the second edition of "Tomorrow: A Peaceful Path to Real Reform"). London: S. Sonnenschein and Co., Ltd.

Hudson, Robert B. 1934. Radburn: A Plan of Living. New York: American Association for Adult Education.

Jacobs, Jane. 1961. The Death and Life of Great American Cities. New York: Vantage Books.

Jarvis, Frederick D. 1993. Site Planning and Community Design for Great Neighborhoods. Washington, D.C.: Home Builder Press.

Katz, Peter. 1994. The New Urbanism: Toward an Architecture of Community. New York: McGraw-Hill, Inc.

Krieger, Alex. 1991. "Since and Before Seaside.” Towns and Town-Making Principles. New York: Rizzoli.

Leccese, Michael, and Kathleen McCormick (eds.). 1999. Charter of the New Urbanism. New York: McGraw-Hill.

Lynch, Kevin. 1960. The Image of the City. Cambridge, MA: Technology Press. 1990. Wasting Away. San Francisco: Sierra Club Books.

Martin, Michael David. 1996. "Back-Alley as Neighborhood Landscape." Landscape Journal 15(2): 138-153. 1999. "Open-back Neighborhoods: Three case Studies." Landscape Journal (forthcoming).

2001. "The Landscapes of Winnipeg's Wildwood Park." Urban History Review/Revue d'histoire urbaine.

Meyer, Elizabeth K. 1997. "The Expanded Field of Landscape Architecture." Ecological Design and Planning. New York: John Wiley and Sons.

Miron, John R. 1988. Housing in Postwar Canada: Demographic Change, Household 
Formation, and Housing Demand. Kingston and Montreal: McGill-Queens University Press.

Mubanga, Pascal. 1974. Wildwood Park Study (unpublished research report, University of Manitoba).

Nelson, Carl R., Jr. and Donald G. Crockett. 1984. Wildwood Park Study (unpublished research report, (c) Carl R. Nelson Jr.)

Newman, Oscar. 1969. Physical Parameters of Defensible Space, Past Experiences and Hypotheses. New York: Columbia University Press.

Parsons, Kermit Carlyle (ed.). 1998. The Writings of Clarence S. Stein. Baltimore: The Johns Hopkins University Press.

Radburn Association Board of Trustees. 1997. "The Radburn Association Guidelines of Architectural Control." Radburn Bulletin, no. 2766. Fair Lawn, New Jersey: The Radburn Association.

Rapaport, Amos. 1969. House Form and Culture. New York: Prentice-Hall.

Reimer, Mavis. 1989. Wildwood Park through the Years. Winnipeg: Wildwood History Book Committee.

Richert, Evan D., AICP and Mark B. Lapping (guest editors). "Ebenezer Howard and the Garden City." Iournal of the American Planning Association 64(2): 125-132.

Schaffer, Daniel. 1982. Garden Cities for Amer ica: The Radburn Experience. Philadelphia: Temple University Press.

Schmitz, Adrienne and Lloyd W. Bookout (eds.). 1998. Trends and Innovations in Master-Planned Communities. Washington D.C.: The Urban Land Institute.

Smith, Lawrence Berk. 1974. The Postwar Canadian Housing and Residential Mortgage Markets and the Role of Government. Toronto: University of Toronto Press.

Stellhorn, Paul A. (ed.). 1978. Planned and Utopian Experiments: Four New Jersey Towns. Trenton: New Jersey Historical Commission.

Tennenbaum, Robert (ed.). 1996. Creating a New City: Columbia, Maryland. Columbia, MD: Perry Publishing.

Toews, Siegfried. 1974. A Tribute to Wildwood Park (unpublished research report, University of Manitoba).

Unwin, Sir Raymond. 1932. Town Planning in Practice: An Introduction to the Art of Designing Cities and Suburbs. London: Ernest Benn.

The U. S. Resettlement Association. 1936. Greenbelt Towns: A Demonstration in Suburban Planning. Washington, D. C.

\section{Further Reading}

Appleyard, Donald. 1981. Livable Streets. Berkeley: University of California Press.

Brower, Sidney. 1998. Good Neighborhoods: A Study of In-town and Suburban Residential Environments. Westport, CT: Praeger Publishers.

Brownstone, Meyer and T. J. Plunkett. 1983. Metropolitan Winnipeg: Politics and Reform of Local Government. Berkeley: University of California Press.

Cooper Marcus, Clare and Wendy Sarkissian. 1986. Housing as if People Mattered. Berkeley: University of California Press.

Francis, Mark, Lisa Cashdan and Lynn Paxson. 1984. Community Open Spaces: Greening Neighborhoods Through Community Action and Land Conservation. Washington, D.C.: Island Press.

Gehl, Jan. 1987. Life Between Buildings. New York: Van Nostrand Reinhold.

Hester, Randolph T. Jr. 1975. Neighborhood Space. Stroudsburg, PA: Dowden, Hutchinson \& Ross, Inc.

Lehrer, Ute Angelika and Richard Milgrom. 1996. "New (Sub) urbanism: Countersprawl or Repackaging the Product." Capitalism Nature Socialism 7 (2): 49-64.

Southworth, Michael and Eran Ben-Joseph. 1997. Streets and the Shaping of Towns and Cities. New York: McGraw-Hill.

Thompson, F. Longstreth. 1923. Site Planning in Practice: An Investigation of the Principles of Housing Estate Development. London: Henry Frowde \& Hodder \& Stoughton. 